\title{
The Allegorical Aüdahiar: An Animated Look at Kazakh National Identity
}

\author{
Jake Zawlacki \\ Louisiana State University \\ Baton Rouge, USA
}

\begin{abstract}
The little-known Kazakh animated film, Why the Swallow's Tail is Forked (1967), written and directed by Amen Khaydarov, not only holds the position as the first example, but is also acclaimed as the greatest work of Kazakh animation by critics, academics, and contemporary animators. The film, based on the traditional Kazakh folk tale of the same name, was significantly altered by Khaydarov in his auteurist direction resulting in a radical retelling. Despite these alterations, Khaydarov's variant of the folk tale resonated with viewers of the period as well as today. In this paper I argue how certain motifs are changed, added, and removed from the original folk tale by Khaydarov, consciously or unconsciously, to incorporate new allegorical elements in the folk tale. This essay takes an "animated look" at the film in that it performs a close reading of a folk tale through a film medium. After performing a shot by shot analysis, I deconstruct alleged "traditional" Kazakh elements, then analyze the dreamlike nature of pastoral national identity, the interplay of film, written, and spoken folklore, and the rhizomatic structure of folklore through audio and visual elements. Ultimately, I return to the film and display it as a construction of a specific nationalist narrative thus shedding light on the broader pastoral nationalist vision.
\end{abstract}

Introduction

While touring the grounds of Kazakhfilm studio with Gali Murzashev, a contemporary Kazakh animator who once worked under the late Amen Khaydarov in the 1980s, Why the Swallow's Tail is Forked (1967) (1) arose in our conversation. Gali offered his personal experience about the film and said it brought tears to his eyes, that it made him proud to be Kazakh, and that it motivated him to become an animator [Zawlacki 2019].

In speaking with Sofia Sultankhan, a secondary school teacher in Olgii, Mongolia, the capital city in the ethnically Kazakh province of Bayan Olgii, Khaydarov's tale found me once more. Sofia retold the folk tale, nearly identical to the plot of the film, of the three-headed dragon king and said it had been taught in primary school when she was young, stating she'd even seen the dragon in a textbook [Zawlacki 2019]. (2) When asked about other versions of the folk tale, she did not know of them. Even in the furthest reaches of Kazakh geography, Khaydarov's tale had seemingly become canon. 
In my conversation with Gali, I brought up the differences between the original folk tale and Khaydarov's film, but Gali shook his head in dismissal. He told me, "[The story] was Khaydarov's. It was Kazakh" [Zawlacki 2019].

I first encountered the film during my last day of language class at Nazarbayev University, the preeminent university in what was then Astana, Kazakhstan. While I sat for the short ten minutes, my classmates and I celebrated a completed summer with the world of Swallow by Amen Khaydarov. The film retold the traditional Kazakh folk tale of the same name. It began with a mother and child living in an idyllic springtime pasture, and then moved into snowcovered mountains where an aging three-headed dragon thirsted for rejuvenation. After consulting a fox shaman and ordering a mosquito to obtain life-giving blood, the dragon king waned as he waited for the return of the insect. Once the mosquito finally extracted the blood of the innocent Kazakh child, his task was complete, and he returned to the dragon's lair. Fortunately, the swallow intercepted the mosquito, conquered the dragon, and saved the mother and child.

In this essay, I uncover how a uniquely Kazakh pastoral nationalist vision, an ideation that entwines the foundation of the nation of Kazakhstan with its nomadic history, was represented through the Kazakh language version of Swallow. By deconstructing cultural elements and motifs within the film, I reveal the many variables that became Kazakh during a period when Khrushchev's Thaw had opened the door for a reexamination of the Soviet project and past crimes. I demonstrate that the concept of "Kazakh" was created in a specific context for certain reasons. What at first appeared to the audience as aboriginally Kazakh, as a particular vision of national identity, was in fact a culmination of relatively arbitrary elements, past and present, found across contemporary national boundaries in Central Asia and beyond. I argue there are elements of the film deeply resonant with Kazakh viewers at its inception and in contemporary discourse, despite their not being originally Kazakh.

I will perform a close reading of the film and, in the spirit of Eric Hobsbawm [1992], deconstruct "traditional" Kazakh elements. Because of the film's interwoven elements of folkloristics, art history, history, and ethnomusicology, this essay grounds itself in the shot by shot reading of the film. By taking an "animated look," I plan to apply approaches from these different disciplines to uncover the film's constructed nature as a defining moment in Kazakh national identity. Armed with this interdisciplinary approach, I aim to shed light on aspects of the film by looking at etymological roots, pre-national history, the massive losses during Soviet occupation, and other historical and cultural moments. Understanding the context of these synthesized Kazakh components will became foundational in interrogating the film as an allegory for Kazakhness.

Following the close reading and deconstruction of the film, I will apply the theoretical approach of the ethnomusicologist Thomas Turino to analyze the constructed nature of national identity. My analysis will be supported using concepts I borrow from Benedict Anderson, the prominent theorist on nationalism, the psychoanalytic folklorist Geza Roheim, literary theorist Linda Hutcheon, the folklorists Roman Jakobson and Petr Bogatyrev, the filmic 
folklorist Juwen Zhang, and the philosophers Gilles Deleuze and Felix Guattari. Ultimately, we will return to the film and see it as a construction of a specific nationalist narrative, one that holds surprising allegorical elements of loss through the inclusion of the Airdahar, thus exposing unseen aspects of the broader nationalist vision. This essay hopes to illuminate how seemingly authentic portrayals of national identity are displayed in popular culture and operates under the assumption that constructed artistic representations can reveal the complexity of nationalist narratives.

\section{Domestic and International Context}

Trained in Soviet animation in Moscow, Amen Khaydarov (Амен Хайдаров or Әмен Қайдар) (3) worked mainly in set and background design at Kazakhfilm before directing his own animation film [Nugerbek, Nauryzbekova, Mokysheva 2005: 160-163]. Given the inexperienced crew he worked with, his naïveté as a director, and the significant alterations he employed in the narrative, it is a marvel that Why the Swallow's Tail is Forked was a universally acclaimed success. Despite the film's international obscurity today, it received two significant accolades: a prize at the 1968 All-Union Film Festival and the bronze medal at the 1974 New York Animation Festival [Torsynbaiuly 2012].

Many early 2010s newspaper articles on Kazakh animation archived at the National Library in Almaty, Kazakhstan, concur with the awards of the past. Among critics, there is consensus around its position as the best Kazakh animation film [Ibragimova, 2010: 26-29; Nugerbekov 1980: 134-138; Baimyrzaeva and Khorabai, 2014: 8-13]. In a series of interviews with contemporary animators written by T. Jurgenov of Al̆qyn magazine, the film is never mentioned explicitly, but a single still looms over the text like a god, a lone frame reminding the reader of its status [2015:3]. What started as a small state-funded project to create a highquality animation film became - in the present day-mythic in its reception and reputation. This film has rooted Kazakh animation tradition from the beginning.

In art historical discourse, Khaydarov fits within an animation movement referred to as the period of "plasticity" by Russian scholars [Nugerbek, Nauryzbekova, Mokysheva 2005: 162]. (4) Laura Pontieri, a scholar of Soviet animation of the 1960s, argues that the time was not only an instant when authorities held less power than before [2012: 75], but also a moment in which animation directors were able to enact a "pure manifestation of the artist's subjective vision" [2012: 2]. This movement sits in stark contrast to a previous era where censors worked side by side with directors, and instead allowed for the artist to exert personal sensibilities. Khaydarov was one of the early Kazakh filmmakers who became what is referred to as an auteur in film scholarship, a concept that had not existed in Russian cinema for decades. (5)

By being freed from the previous constraints of film censors, Khaydarov was able to depict Kazakh culture in a novel way. Not only has Swallow been considered the quintessential example of Kazakh animation by critics and audiences alike, its position has also solidified within discussions of broader 
Kazakh cultural identity and national identity. To fully understand the nuances of the film, however, one must first look at the film's many intersecting narratives and its constructed nature. The intricacies of this important cultural product have never been fully examined; this essay will take an "animated look" to scratch the surface of a folk tale through the lens of a children's animation film.

\section{Why the Swallow's Tail is Forked}

\section{Imagined, Commemorated, and Dreamt Realities}

The film opens with a shot that quickly zooms into the mother and child. It begins with whimsical dreamlike music, common in fairy tale film introductions, and positions the viewer as if they were dropping into a dream from the clouds above. We can read the opening of the film as displaying the intimate relationship between folk tale and dream as posited by the first psychoanalytical folklorist, Geza Roheim. Roheim's persistent thesis argues that all folklore originates from dreams [Roheim and Dundes 1992: xvii]. While the viewer is lulled into a dreamlike state by the music and mother's rocking of the traditional cradle board, the viewer is comforted by this pastoral past.

Roheim's proposed relationship between dream and folk tale is memorable because it suggests the dreamlike nature of identity formation. Remembering the oft cited Benedict Anderson, communities are imagined as a result of various factors: print media, mapping, and censuses, to name a few [2006]. (6) Considering the difference between the imagined and the remembered, Bruce Privratsky offers this in regards to Soviet collective memory, "[Commemoration] is a processing mechanism by means of which people reach back into their past, idealizing and criticizing it, and thus articulate a future for themselves" [2015: 19]. (7) In my animated look of Swallow, I suggest that if communities can be actively imagined, as Anderson defines it, and commemorated, in Privratsky's sense, then it follows: they can be collectively dreamt, or day-dreamt, into existence. After the experience of a vivid dream, one often idealizes selected aspects and entirely forgets or misremembers others. If this story could be treated as a dream of Kazakh collective identity, what might each element and motif tell us about a Kazakh reality? Only as a completely lucid participant can we notice seeming trivialities that might be forgotten upon wakefulness. 


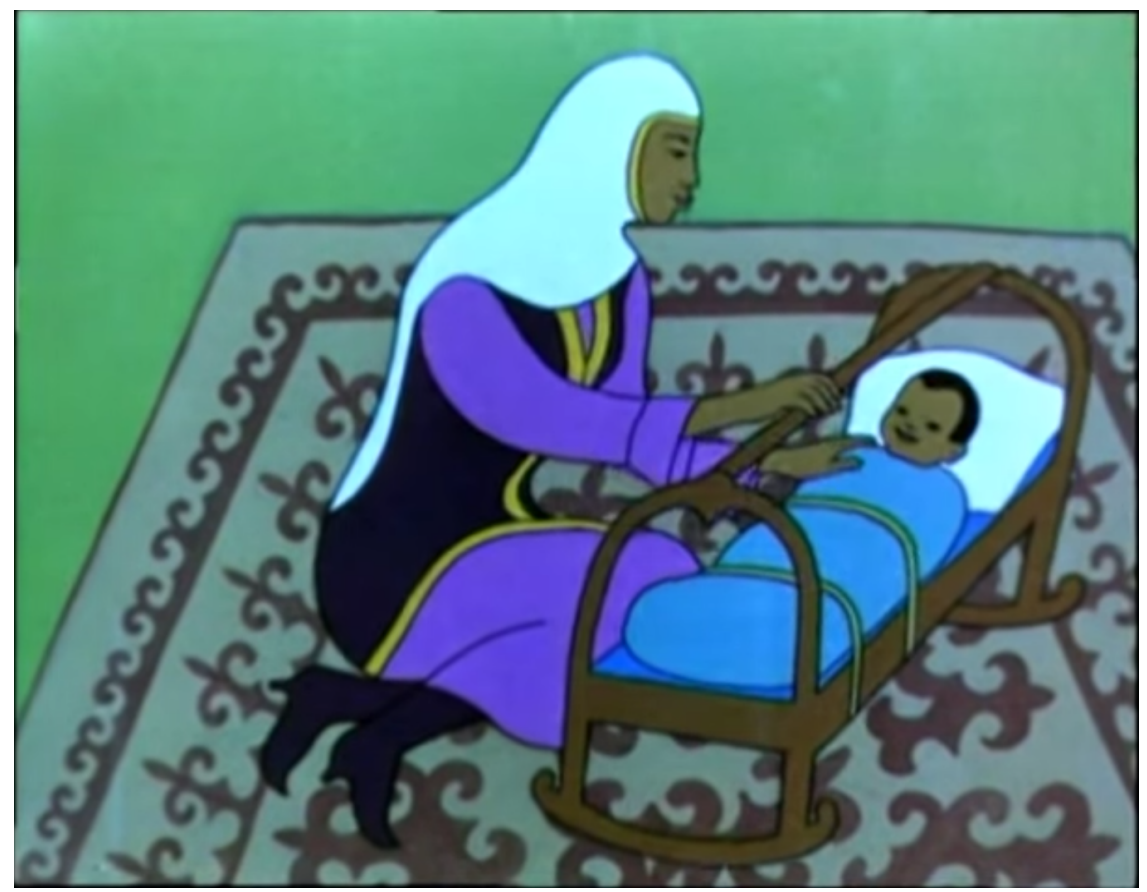

Image 1: The mother tending to her child surrounded by traditional Kazakh items. [Why the Swallow's Tail is Forked, 1967]

The mother wears a kimeshek, a traditional head scarf, tending to her child in a traditional Central Asian cradle board, besīk, on top of a traditional felt woven rug, tekemet [Image 1]. Immediately, the audience is confronted with objects representative not only of the Kazakh cultural past, but of the past that had, in theory, been left behind, or intentionally erased. In the 1960s, following Khrushchev's ousting and the political Thaw, the people of the Soviet Union compared their lifestyles to those of Europe and the United States through television, music, and film, and developed different tastes in fashion as a result [Kozlov and Gilburd 2013: 402-435]. The kimeshek would have been regarded as old-fashioned, dated, Islamic, parochial, and indicative of a pre-Soviet time period. The besik would have existed in villages and some city dwellers' homes, but is a tradition closely tied to rural, provincial, village life [Zawlacki and Derrick 2020]. The tekemet is one of many representations of Kazakh felt art traditions, but its place in the film represents the cultural standing of traditional felt rugs, carpets, and tapestries. In Central Asian Art, Vladimir Lukonin and Anatoli Ivanov note [2013: 182] that following the forced sedentarism of nomadic groups, "Many utilitarian objects of the past became souvenirs." The inclusion of these items in the film reaffirm their integral and purposive position within the pastoralist tradition. 
A few seconds later, the shot moves to the mother helping a fallen swallow fledgling. She picks up the fledgling and returns it to the nest in a gesture of harmony between humans and animals [Image 2]. (8) This seemingly basic motion of kindness conveys cosmological significance within the Kazakh cultural milieu.

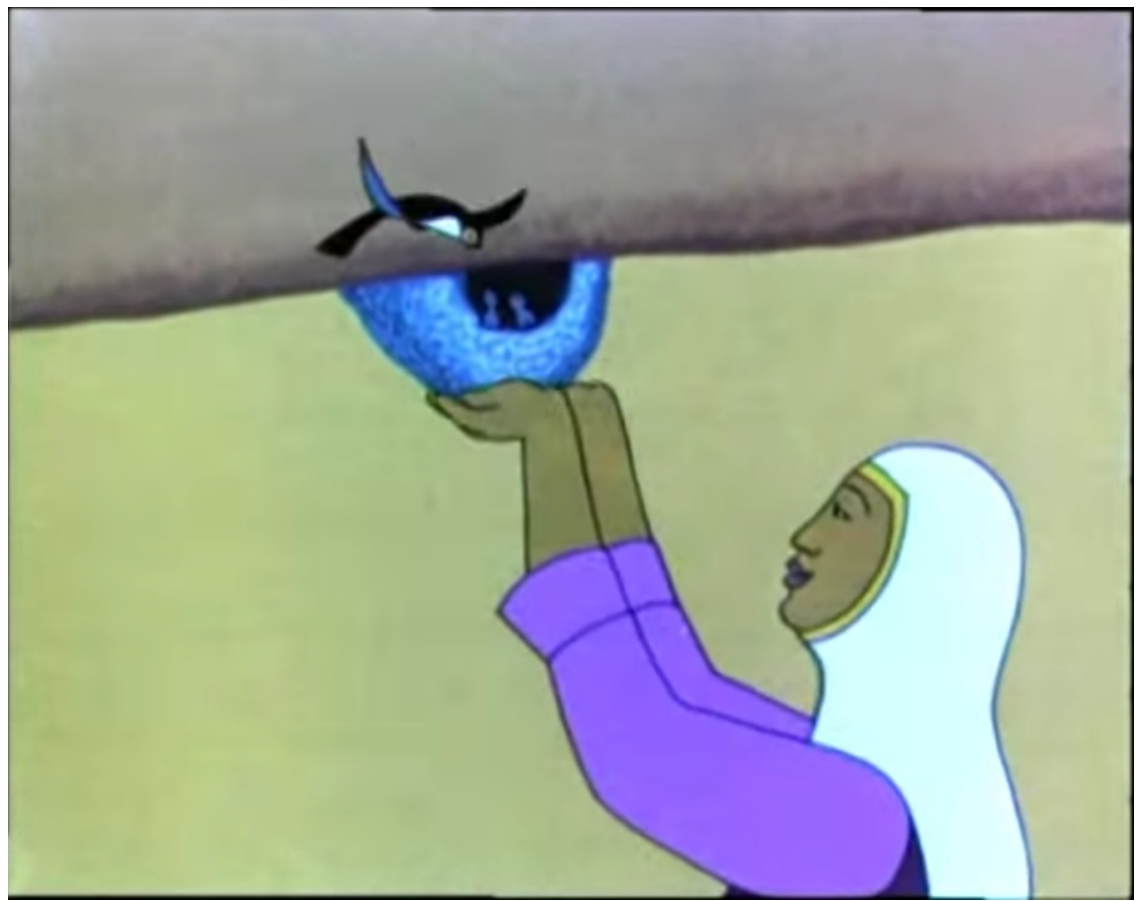

Image 2: The mother returns the swallow fledgling to its nest. [Why the Swallow's Tail is Forked, 1967]

\section{Cosmological Context}

While competing histories of religion exist in contemporary Kazakhstan, scholars such as Thierry Zarcone and Angela Hobart have pointed out [2013: xxii] in Shamanism and Islam: Sufism, Healing Rituals and Spirits in the Muslim World, that "[Kazakhs] remained firmly respectful of their animist and shamanic past and had a veneer of Muslim culture only." (9) Because of the nomadic nature of those living on the steppe, the cultural crossroads that was Central Asia, and the deeply ingrained animist/shamanist indigenous faith, Islam never fully took hold as a substantive religion. Islam was introduced to pre-Kazakh nomadic tribes in the $9^{\text {th }}$ and $10^{\text {th }}$ centuries along what is now called the Great Silk Road, but was unable to establish roots because of the constant wanderings of the nomadic people. Islam conflicted with the indigenous practice of Tengrism, an allencompassing cosmology that included elements of shamanism, animism, monoand polytheism, and ancestor worship that was widespread in a broad geography 
we now call Central Asia [Basilov 1989: 59]. This is not to say Islam was inherently contradictory for nomads of the steppe, but rather that it was difficult to gain traction among those who already had a deeply rooted belief system and who were unable to accommodate the five pillars of Islam (10) into their lives [Zawlacki 2019; Geraci and Khodarkovsky: 2001; Zarcone and Hobart: 2013].

It is difficult to find vestiges of Tengrism in contemporary Central Asian society. This leaves the proposed tripartite model of Shamanism open to critique because of this erased past. Ronald Hutton, in Shamans: Siberian Spirituality and the Western Imagination, argues [2001] the three-world model is an oversimplification of complex cosmologies, it is still the most prominent understanding of Tengrism.

The cosmological worldview of Tengrism consisted of three parts: a heavenly world, a subterranean world, and the human occupied middle world. Humans act as the bridge between the three worlds, with shamans given the specific task of maintaining this balance through rituals and musical performances. Tengrism is also hierarchical in the sense that not all living things occupy the same world. The heavenly world is ostensibly the most correct version of the middle world, containing sacred animals, such as swallows, swans, horses and animals specific to a given region [Zawlacki 2019]. The middle world consists of all animals with no special distinction given to humans. Thus, when reading Swallow, it is important to remember the cosmological distinction between the human and the bird. This explanation contextualizes the act of the mother as she aids a sacred animal from the middle world. She is in a position to provide assistance and does so, helping the swallow chick back into the nest, and into the upper world of the sacred birds. The subterranean world, on the other hand, consists of human-like creatures as well as animals such as snakes and insects. Creatures featured in the film — such as the mosquito - represent the lower world that is potentially cosmologically dangerous to the middle world and its inhabitants.

The cosmological connection with nature that defined nomads of all kinds had been reimagined in the brutal years of collectivization and was ultimately a thing of the past [Cameron 2018: 91]. Harmony still existed among humans and animals, in the sense of rural villages with large plots of land for animals to graze, but the spiritual connection and nomadic lifestyle was forever changed in the wake of forced collectivization in the late 1920s and early 1930s.

\section{The Swallow in Kazakh Culture}

As noted in the preface of Giuseppe Pitre's The Swallow Book [2016: 5], "Because of her sociable habits and her friendly disposition, the swallow from earliest times has been observed and beloved by all the peoples of the world." Kazakh culture is no exception. The swallow assumes particular significance in the film and folk tale as an animal that not only occupied the heavenly plane of existence in Tengrist cosmology, but held symbolism in multiple Kazakh cultural traditions, practices, and legends. 
One of these cultural practices is Tūsaukeser, the Kazakh practice of celebrating a toddler's first step. The ceremony symbolizes the initial steps in life by cutting a black and white rope binding the toddler's legs. Besides the obvious umbilical reference embedded in the ceremony, the coloration, mirroring the swallow, represents the harmony of good and evil [Nysanbaev 1998]. By cutting the rope, the toddler is imbued with the wisdom of being able to distinguish good and evil in his or her walk through life. Similarly, the swallow's coloration is connected with the dichotomy of good and evil, as the swallow often possesses the wisdom to guide between them in folk tale iterations. The swallow is key to Kazakh self-perception as it exists in Kazakh practices, Tengrism, the nomadic lifestyle, and Kazakh history. (11)

In the long pan across the hillside, a variety of subjects are introduced in the shot. (12) The first two objects in the opening credits scene are the traditional mudbrick house and the nomadic ür. In Magnetic Mountain: Stalinism as a Civilization, Steven Kotkin [1997: 169] investigates the history of the construction of the Soviet mining town Magnitogorsk. During the development of the planned city, administrators were constantly plagued by the mudbrick houses that offered workers relief from the low-quality temporary tents provided by the state. In the eyes of the administrators, the style represented the so-called backwardness of the peasantry and the many non-Russian Soviet citizens working there. Khaydarov's inclusion of mudbrick houses and $u \grave{u s}$ is therefore indicative of the pre-Soviet past. While both buildings in the film are standard representations of historical domiciles, they also represent the reported backwardness Soviet administrators criminalized and constantly tried to eradicate in their social and cultural policies.

As the shot pans to the right, we see two horses grazing on the hills and a balbal, (13) before two more structures come into view [Image 3]. Both have the Islamic crescent moon above rounded domes, but are purposefully opaque in light of the official Soviet position on religion. The larger structures with square-like perimeters seem to indicate mosques, while a few stand-alone structures may be grave sites, tombs, or turbe, a tomb that is the site of a pilgrimage. The light coloration of the bricks, indicative of weathered mudbrick buildings in general, is emblematic of both structures. However, the ambiguity of the structures is less important than the obvious Islamic iconography in the crescent moon. This iconography suggests the inseparability of Islamic and Kazakh identities in the pastoralist past. Given the relatively recent history of Kazakh Islamicization and deep Tengrist ties, this portrayal of Islamic sites suggests an ancient relationship between Kazakhs and Islam, and yet it was not until the 1860s that mullahs, schools, and mosques appeared on the southern edge of what is now Kazakhstan [Geraci and Khodarkovsky 2001: 280]. Thus Khaydarov, intentionally or not, creates a reimagined vision of the pastoral Kazakh past as Islamic. While the Islamic structures are not purely anachronisms, this image reduces a complicated past of religious variety and replaces it with a unified religious and cosmological vision. The representation of Islamic cultural artifacts in the film illustrates one of the many elements of Kazakh identity historicized as a part of the pastoral 
nationalist identity in Khaydarov's retelling. As we have seen, these various aspects all function to establish the "Kazakhness" (14) of the folk tale, despite the tale itself having been created long before the notion of "Kazakh" existed (see below for discussion).

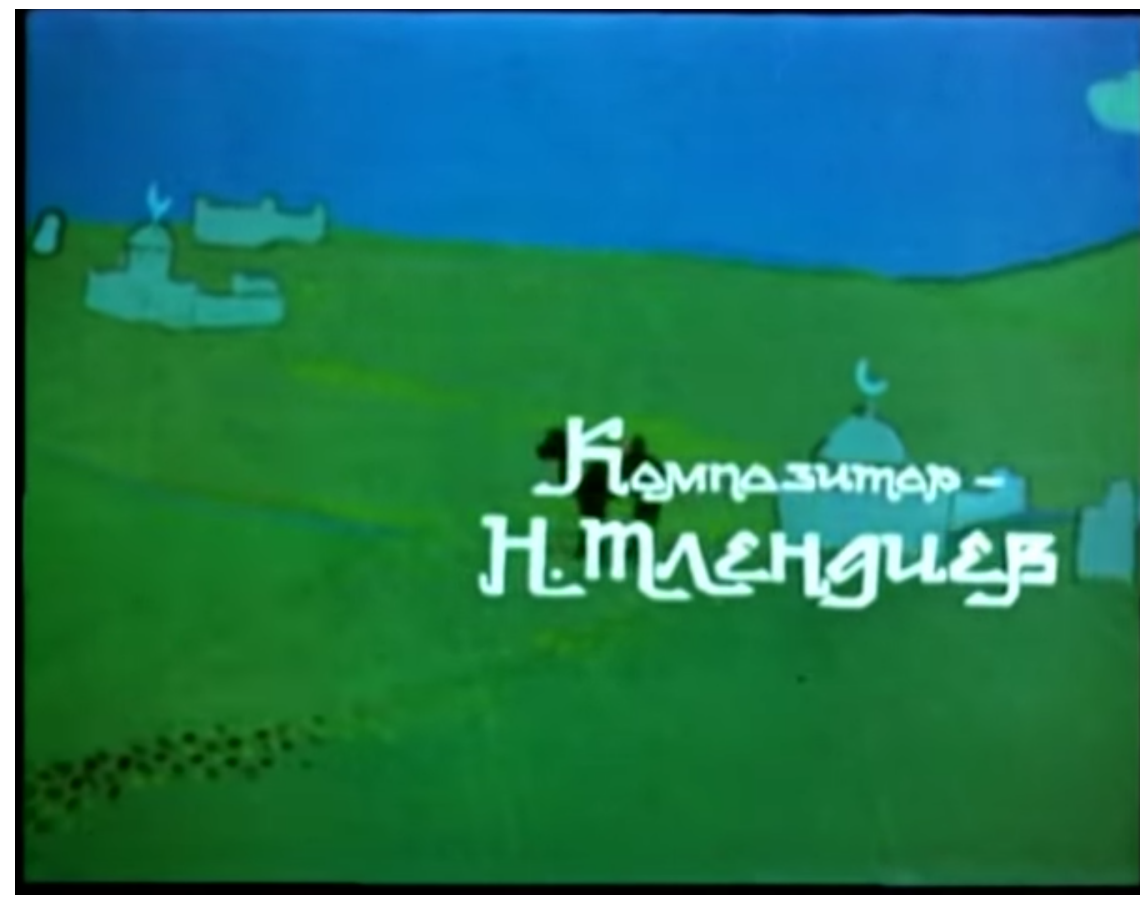

Image 3: The shot pans across vague Islamic structures in the countryside. [Why the Swallow's Tail is Forked, 1967]

A significant element of the film not yet mentioned is the critical role of sound. In order to position the Western orchestral and traditional Kazakh music of the film, we must first begin with the verbal aspect of sound in the film. The entirety of the Kazakh language narration in the film rhymes, which roots it in a long lineage of Central Asian, specifically Islamic, rhythmic modal poetry found in the Kyrgyz epic of Manas or the works of Kazakh poet Abai Khunanbayulu, to name two examples of this rich tradition. The lilt of the narrator's voice entices the viewer by elongating Kazakh words and phrases and placing the vowel stress in unusual parts of the word for the sake of rhyming or emphasis. This aspect of narration calls to a pedigree of Islamic poetry and legitimizes the folk tale as well. The choice to rhyme the narration was conscious on the part of Khaydarov, because it brings in an additional element of tradition into the film.

The opening shot of the film carries a fairy tale musical melody as the audience begins to fall into a dream. It feels familiar, and would have even to the inexperienced film viewer of the time, in that it creates a sense of wonder and 
peace, like a tale itself. In addition to the objects seen while panning across the countryside, the viewer hears an altogether different type of music, that of the Kazakh kǚ.

\section{The Kazakh Kü}

The Kazakh kǚ is a musical tradition defined by its wordless instrumental narrative. (15) Generally, a kǚsh $\bar{\imath}$ [күйшi], performer of kǚs, begins the musical performance by telling a short history and providing context for the kiü he or she is about to play. In a traditional, communal, and live music-making context, after the short, spoken portion of the performance, the musician would begin to play the dombyra, a two-stringed lute instrument, or qobyz, a traditional horsehair twostring instrument. (16) As the küush $\bar{\imath}$ would play, the kü $\breve{\imath}$ would imitate aspects of a narrative, sometimes described beforehand, sometimes hinted at in the title of the küu, but always mimetic. Strumming and plucking hand motions often revealed narrative elements. As Theodore Craig Levin and Valentina Süzükei [2006: 133] have noted in the instrumentation of the Tuva people, kǚs relating to birds, for example, include hand motions that indicate the flapping of wings or splashes of lake landings. These performative qualities could be parts of interpretative sonic narratives that mark the kiü as a unique musical practice.

The kǚ that plays during the introduction credits of Swallow is Aqqu, White Swan, another sacred bird in Tengrist cosmology, performed by Nurgisa Tlendiev. Tlendiev was the writer of the score for Swallow as well as for numerous other films, both animated and live action, at Kazakhfilm film studio for over twenty years. (17) Tlendiev's Aqqu follows a lineage of kǚs titled the same, all telling a similar narrative, with similar instrumentation. Kǚs never exist in a vacuum; they are always a part of the lineage of previously performed küs [Levin, Daukeeva and Köchümkulova 2016: 279].

An explanation of Aqqu's narrative can best be displayed in a traditional qobyz performance by Raushan Orozbaeva [2014]. The Kazakh qobyz was uniquely associated with shamans in pre-Soviet times because of the shaman's healing ability while replicating the sounds of animals [Levin, Daukeeva and Kóchumkulova 2016: 331-337]. With this fact in mind, we can identify the mimetic quality of Orozbaeva's performance. The opening of the kü mimics the sounds of a swan's call with surprising accuracy. As the kü progresses, sounds of wings flapping and swan calls echo throughout. The single plucks of the horsehair string represent the missed arrow shots from a hunter in the bushes. As the swan rises from the pond, dodging the interspersed plucks, the kü $\breve{i}$ softens in volume. The plot builds in tension until just as the listener thinks the kiü is over and the swan has escaped, a final pluck indicates the true shot of the hunter's arrow.

The story of the swallow is told through a tradition that cannot be attributed to a singular author. Historically, kiü performances would end with the performer saying, "de $\breve{\imath} \vec{\imath}$ " or "dombyra de $\breve{\imath} \vec{\imath}$ " meaning, "it was said" or "the dombra said." This phrase shows the intersecting, interrelated position of instrument and performer. They both have agency, yet share personhood. The performer is merely 
a conduit necessary for the instrument to speak; the dombyra and qobyz act as agents in telling stories in a separate non-linguistic musical language. (18) Kazakhs, and the many other Central Asian ethnic groups, understand instrumental language through a strong lineage of wordless narrative traditions [Levin, Daukeeva and Kỏchümkulova 2016: 278].

Tlendiev takes aspects of this traditional kü and molds it by varying the composition. In Tlendiev's performance of Aqqu, we follow the flight pattern of the bird through the rhythmic picking and strumming in the kiü, recalling for the listener the flapping of birds' wings. As tension rises, Tlendiev's strumming doubles in quickness and flutters between notes in a sonic struggle representing the quickened pace of the wing flaps. The notes rise and fall in tension before finally returning to the normal flying rhythm of the swallow. Similar to the individual stylistic differences in recitations of oral epics in Central Asia, as well as in Eastern Europe, the narrative of the kiü is adapted in every telling [Lord 1960]. Tlendiev maintains motifs from more traditional versions of the küu, but contributes distinct differences that add dramatic tension and elements specific to the plot of Swallow.

After the opening credits, the next scene opens with Kazakh language voiceover narration as the camera zooms into the clouds between two snow-capped mountain ridges revealing a door carved in the side of a rock. Behind the large doors lies a black three-headed dragon with three minions to the left of the shot. The narrator speaks of a dragon king who had lived in the mountains for a long time and was now dying. The three fantastical creatures then carry the heads of the dragon to the open windows in what becomes one of the most compelling feats of artistic direction in the film. As the dragon's heads hang outside the rock wall windows, a yellow outlined ghost of a thinner, more vicious dragon bursts forth [Image 4]. The statement most clearly made by these actions is that nothing escaped the wrath of the dragon king in his prime. Threes resonate throughout the film as the narrator recounts the savagery of the Aüdahar's rule while the ghost dragon engulfs animals of air, land, and sea: ducks, deer, and fish. All creatures were subject to the terror of the dragon king: creatures of the upper, middle, and lower realms of the Tengrist cosmology. Khaydarov's illustration of the wrathful dragon is so convincing one might assume the dragon's aboriginal place in all tellings of the folk tale. Surprisingly, Khaydarov's Ä̈dahar stands in stark contrast with previous versions.

\section{Baurjan Momusholu's Account}

Baurjan Momusholu's well known Kazakh novel Native Home [1918/2003: 29-31] includes an account of this folk tale spoken by a grandmother to a child caught teasing a swallow. (19) The story is told as a way to teach the child to respect animals. I will provide a brief summary of this episode in Momusholu's novel for comparison. 


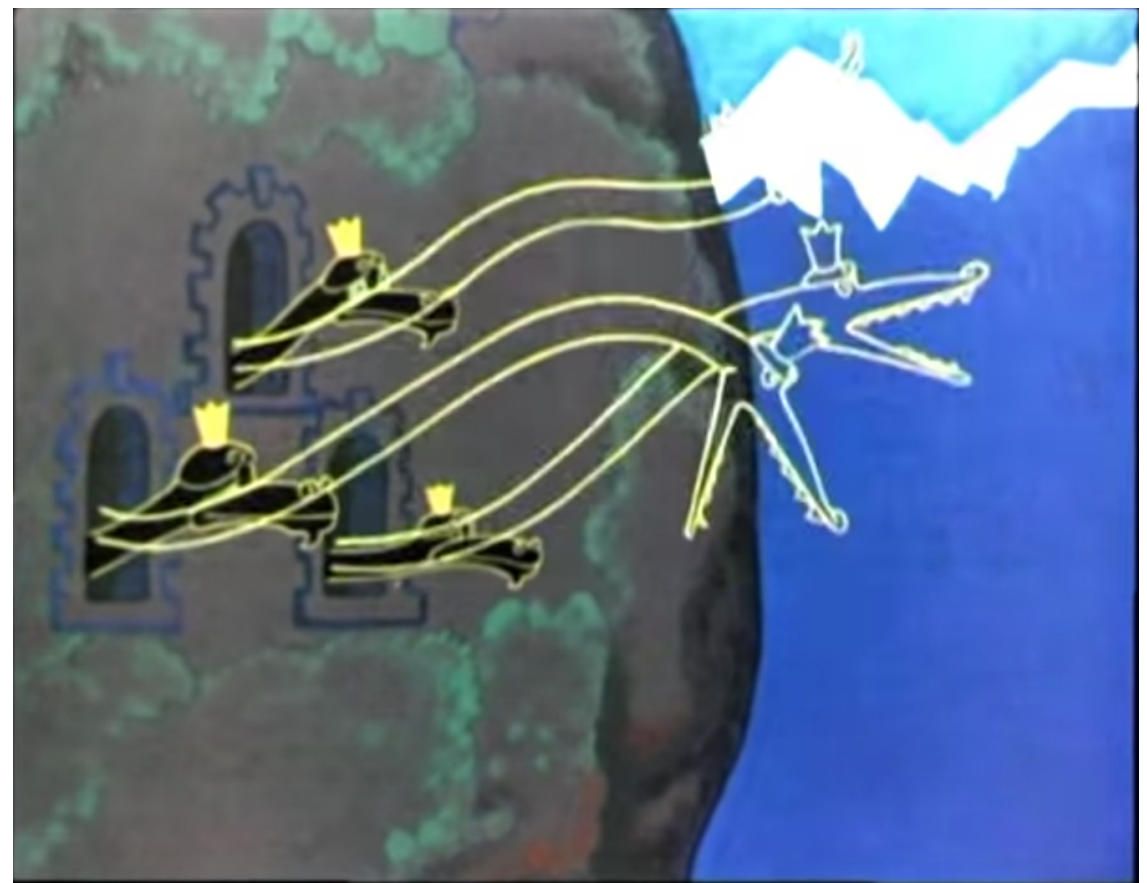

Image 4: The younger Aidahar of the past bursts forth from the memory of the dragon king. [Why the Swallow's Tail is Forked, 1967]

A snake had come to King Suleiman's castle after successfully defending the king's land. (20) The king expressed his gratitude and asked if he could grant the snake a wish. The snake first confesses his base placement on the Earth as a wingless, armless, and legless creature that invoked fear among all who see him, and then asks to know the animal with the tastiest blood in order to know what to eat. Suleiman, able to speak the languages of all animals, sends the flying insects in his kingdom across the Earth to find the tastiest blood.

Sometime later, the swallow sees the mosquito returning to Suleiman's castle. The swallow asks the mosquito twice which animal had the tastiest blood, but the mosquito refuses to answer. Upon the last probe by the swallow, the mosquito shouts that human's blood is the tastiest. The swallow accuses the mosquito of lying, but the mosquito does not relent. The swallow then attacks the mosquito and pulls its tongue from its mouth. Seeing the bees and wasps returning to King Suleiman, the swallow also plucks their tongues from their mouths. Once the insects return to Suleiman, he asks what they found, but they are unable to speak, making unintelligible buzzing noises. Suleiman says that he cannot understand them and asks again what they found. 
The swallow, flying above the scene, says to Suleiman that she understands what they are saying, and that frog's blood is the tastiest. (21) Suleiman trusts the swallow and decrees that the snake is to eat frogs. The snake accuses her of lying to Suleiman, but the king remains unmoved and states he cannot alter a decree. Out of frustration, the snake lunges at the swallow and pulls the middle feathers from her tail. The story ends with the grandmother restating the protective qualities of the swallow over humans and how swallows must always be respected.

Comparing these iterations of a classic Central Asian folk tale elucidates complex changes. The film's story is written by Amen Khaydarov himself with no reference to any other writer or legend. The most obvious aspect changed is the Abrahamic allusion. The King Suleiman of Momusholu's version is not just a placeholder for a king, but uses his skill of speaking to animals, as observed in other accounts of Suleiman. (22) The second Abrahamic aspect of the narrative is that of the snake. In the snake's appeal to Suleiman as a wretched creature, we are reminded of the Abrahamic associations in the garden of Eden. These changes on the part of Khaydarov to shift from Abrahamic characters and mythologies to alternate mythologies have repercussions. In changing the accepted tale of Suleiman and the snake, still seen in contemporary retellings as recent as 2017 [Seitzhanov, Ponomareva and Baigabulov 2017: 27-31], Khaydarov shifts the audience's traditional associations with the folk tale. There could have been advantages for Khaydarov to make the story less explicitly religious, but as the film itself has shown, there are subtle references to Islam through images of mosques and gravesites, and in the lilt and rhyming of the narration. This shift away from explicit references to Islam, the removal of King Suleiman for instance, could have been to avoid censorship. Considering the only references to Islam are in quick shots and vaguely referenced in the lilt of the narration, they may be potentially too subtle for the average viewer to notice. Unless the viewer is intently looking, and listening, he or she might not notice the mosque in the fast-paced pan across the hillside, nor the subtle nod to traditional Persian Islamic poetry through the tale narration.

\section{Khaydarov’s Aĭdahar: Neither Serpent nor Dragon}

The replacement of the snake with the Alddahar by Khaydarov is effective for a multitude of reasons. Firstly, a three-headed dragon compared to a single snake offers an incredible opportunity for creative animation. Separate heads equate separate motion thus displaying a dynamic character. Aesthetics aside, three heads, three windows, and three minion creatures resonate with the tripartite Tengrist cosmological view, as well as the three dominions of the dragon's past: air, land, and sea. These three divisions are even seen in the depiction of the dragon's body itself: wings (air), feet (land), and scales (water/underground). (23)

Kazakh folklore has few instances of dragons. The word "dragon" is difficult to translate as there are multiple variants of the creature in Kazakh mythology. 
Aìdahar, as it is solely referred to in the film, holds the additional connotation of "evil lord" or "demon." These connotations, however, are less important than the Aľdahar's explicit association with the underworld of the Tengrist cosmology as a being possessing the power to move souls between the middle and lower worlds. Қазақтың этнографиялық категориялар, ұвымдар мен атауларының дәстүрлі жүйесі [The Traditional System of Ethnographical Categories Conceptions and Designations of Kazakhs] makes reference to Vladimir Propp's analysis of dragons as creatures that dwell specifically in urban and sedentary cultures [Nursan 2011: 87]. Propp further explains that because of the sedentary nature of dragons, it would be easy to assume that they are an import from a sedentary culture into Kazakh tradition.

The word Aïdahar complicates this analysis because of the usage of the letter ' $h$ ' in the Kazakh language. As described by T. Kengesbaev and G. Musabaev, [1975] “《h» фонемасы келетін сөздер қазақ тілінде өте аз...және кейбір шығыс тілдерінен енгенсөздарде (sic) (гауһар, жауһар, каһарман) кездеседі” [the letter "h" is rarely seen in Kazakh language... and there are some loan words that came from eastern languages]. The fact that this word is exclusively used for older words, and could be borrowed from one of the sedentary cultures the word Ă̈dahar itself conveys as a loan word from an eastern language (Persian, Farsi, Mandarin, etc.), helps us understand the role of Al̆dahar in the film. Contrasted with the bright colors of the nomadic life in the opening shot, the three-headed dragon king sits in a dark, subdued lair. The coloration not only indicates a subterranean color palette but also urban sedentariness more broadly as it depicts gloomy stone-colored walls. These are not the quick-to-dry mudbrick houses of nomads, but palaces, castles, and homes representing an altogether different lifestyle. This is representative of the monumental divide between the sedentary dragon king and the purported free peoples and animals of the steppe and mountains.

In a brief "dragonological" analysis, I will attempt to differentiate between the varying types of dragons and show their origins. In his analysis of Swallow, B. R. Nugerbek [2005: 162] makes the distinction between the two different portrayals of the dragon in the film. "Ертегідегі Айдаһар-тәтті қанды аңсаған, алып күштің иесі болса, Фильмде ол күні санаулы, қартайған аждаһа" [The dragon of folk tales is bloodthirsty and strong, but the dragon portrayed in the film is an aged Azhdaha]. Azhdaha is also found in Zoroastrianism, one of the oldest known religions centering around a monotheistic principle with a dualist cosmology of good and evil. In Zoroastrianism, Azhdaha originates from "Aži Dahāka," "Aži”" meaning "serpent" or "dragon" and "Dahaka" as a proper noun. In the Avesta, one of the oldest texts of Zoroastrianism, the Azhdaha is depicted as "the three-mouthed, the three-headed, the six-eyed, who has a thousand senses, that most powerful, fiendish Druj, that demon, baleful to the world, the strongest Druj that Angra Mainyu created against the material world, to destroy the world of the good principle" [Darmesteter 2019]. This seems like a faithful representation of the young ghost Aľdahar in the film with one major exception, an Al̆dahar traditionally has a single head. Additionally, the Azhdaha of Kazakh 
culture loses the explicit Zoroastrian associations and is similarly translated as "demon" or "devil." Alternatively, in the Iranian epic, the Shahnameh, the Azhdaha is represented as a giant serpent with wings often defeated by epic heroes [Tousi 2019].

Russian and Eastern European dragon lore add a perspective to these matters, as it complicates Khaydarov's multi-headed dragon. The zmei (змей) of Russian and Eastern European origin is often represented as a three-, six-, or nineheaded dragon. (24) While it is impossible to know which type of dragon Khaydarov implied when he made his film, it is clear that his depiction of the Aĭdahar could have been influenced by any of these mythical creatures. This choice nevertheless illustrates that a core element in the film is not indigenously Kazakh.

These varying manifestations reveal the complexity of "dragonology." No singular entity exists independently from another. The zmei and the Azhdaha could be separate iterations of the same being, originating anywhere between presentday southeastern Europe and Iran. These types of hunts could be interpreted as distracting, but it is important to note that the Aídahiar does not exist alone as a uniquely Kazakh symbol. If it is to represent anything beyond a villain, it would support the interpretation of the Aüdahar as an inherently external foe and a critical representation of otherness. It is first and foremost a creature outside of Kazakhness, a representation of exteriority, of non-inclusion.

Upon the return to the castle of the yellow-outlined Alidahar, or aged Azhdaha, the Al̈dahar hangs his heads in a sign of despair and retreats to his throne. Noticing the dragon's labored breathing, the three minion creatures converse. (25) The narrator informs the viewer that the fox has been brought to the dragon to determine his ailment. (26) The fox looks under the dragon's wings and inside his mouth before writing a spell. The shot includes the notation of the spell in Russian, and reads, "Мощь вернёт властелину вновь, как цветение, живая кровь. Лис [The power of the ruler will blossom once more with life giving blood. Fox]." (27) With fantastical orchestral sounds accompanying the score, the fox whirls his arms and transforms the written spell into a potion bottle. He places a dead fish inside as the narrator explains that upon placing the correct blood in the potion, it will give life to whoever drinks it.

After the potion is created, the mosquito is called by the Aldahiar and receives the shrunken potion bottle from the fox. The mosquito flies to the countryside in search of the correct blood to awaken the dead fish placed in the potion bottle. The mosquito unsuccessfully collects blood from a deer and a donkey before arriving at the mother and child in the countryside. When Nugerbekov [1980: 134] interrogates the psychological effects of animation, he writes about the coloration of the Kazakh textile items in the scene preceding the mosquito attack, stating, "По мере приближения камеры к ребенку мы ощущаем тревогу. Такое настроение нагнетается кроваво-красным цветом орнамента. Наши тревожные ожидания оправдываются: комар жалит ребенка [As the camera approaches the baby we feel anxious. this anxiety is caused by the blood-red color of the textile ornaments. our anxious waiting 
becomes true: the mosquito stings the baby]." The bright colors of the previously comforting tekemet contrast with the impending evil, not under cover of darkness, but in a joyful moment between a mother and child [Image 5].

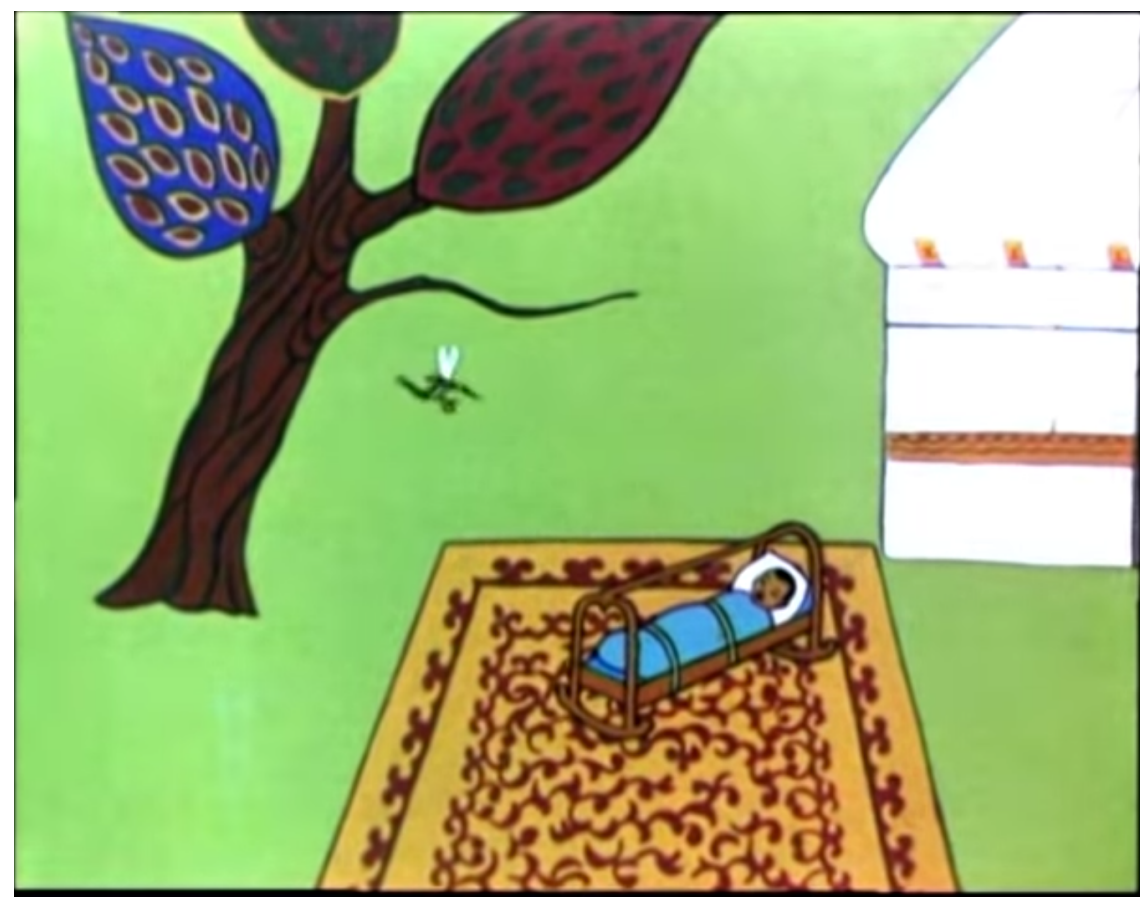

Image 5: The colors of the tekemet foreshadow the attack of the mosquito. [Why the Swallow's Tail is Forked, 1967]

During the shots following the mosquito in its quest for the proper blood, the film alternates to scenes within the castle. The three minions first try to tempt the Aldahar with food to aid him. The middle head raises to meet the plates and shakes its head in refusal, illustrating the Ädahar's frail condition and dependence on others. Following a failed attempt of the mosquito, the film shifts to a dance and musical performance for the Al̆dahar. The three minions play instruments that resemble the Uzbek doyra, the Kazakh dombyra, and a generic reed instrument indicating anything from a Turkic zurna to an Armenian mey. In an attempt to raise the spirits of the king, three mouse dancers enter the castle and perform. The performance continues for almost forty-five seconds before returning to the plot of the film. The scene feels unnecessarily long in the flow of the rest of the film because it adds very little to the plot, but it introduces elements of Orientalism and positions the Aidahar as external. In the music played the listener hears a bright timbre of the reed wind instrument as well as the wide interval, called the augmented second by music scholars. This interval indicates the use of a modal system (mugham, maqom, etc.) that proliferated in the pre- 
Soviet local musical practices of the era. However, the movements employed by the mice are anything but Central Asian and represent an Orientalism of Middle Eastern influences. In other words, a key moment of animation in the film has an imported element.

The luxurious extravagance and belly dance costuming and gestures of the mice herald a widespread orientalist view in the Soviet region. This Orientalism does not seem to demonize the geography of the Middle East, but rather rejects past imperial Persian and Ottoman powers that governed these regions by the music played, the typical belly dancer apparel of the mouse dancers, and the extravagance of the situation. A possibility for why this was included in the film could be because it was the very first sequence of animation the studio had produced. In an archive file at the National Film Archive in Almaty, a 1968 news update about the Kazakhfilm studio shows this very scene in black and white as an example of the studio's work. This could suggest that it was the first actual piece ever produced and acted more as filler than as a necessary piece to the film.

\section{Climax and Resolution}

To understand the significance of the retrieval of blood, we must understand the synthesis of land and people in Kazakh culture. Historically, nomadic peoples have been both colonized and solely historicized through the eyes of non-nomadic peoples. The Greeks wrote of the Scythians, the British wrote of the Australian Aborigines, and the Russians and Soviets wrote of the people of the steppe. In the eyes of empires, nomadic blood always equaled imperial land. (28) Keeping this coupling of geography in mind, we can investigate the notion of blood as cure.

The short reminiscence of the past Al̆dahar consuming everything in air, land, and sea demonstrates the tyrannical rule of the king in the past: he consumed resources. In a final gesture of sovereignty, he moves beyond the metaphorical act of resource depletion, and to the people themselves. As the narrator tells us, "Бесікте жатқан нәресте, ең жұмсақ жемдік емес пе [There wasn't a more vulnerable prey than the newborn child in the cradle]." Synchronous with the Soviet ideology about the Russian imperial past, the Ar̈dahar must literally taste and drink the blood of his human subjects to survive.

After the mosquito extracts the blood from the child, and the potion reawakens the fish within the bottle, he celebrates and then returns to the castle. Fortunately, the swallow intervenes In the chase scene between the swallow and mosquito, musics play a pivotal narrative role. (29) When the shot focuses on the mosquito, Western orchestral music opposes the swallow's pursuit. When the shot alternates to the swallow, however, sections of Tlendiev's Aqqu plays [Image 6]. Without voice-over narration during the chase scene, music acts as another example of narrative mimesis. Unlike Western animation that often uses music to enhance emotional reactions or narrative points, the Kazakh kü acts in a narrative capacity. Tlendiev's Aqqu illustrates the flapping wings of the swallow and carries previous connotations of the sacred bird and the hunt, but the roles have been reversed. The sacred bird becomes the hunter in saving the mother and child from 
being subjects of the Aidahir. With a deeper understanding of the elements of the $k i u$, some audience members watching the film may recognize how the musicality adds to the narrative in a way wholly unique to Central Asian culture. The struggle between the mosquito and swallow does not need to be narrated with words, but rather with the familiar narrative tradition of the kiü.

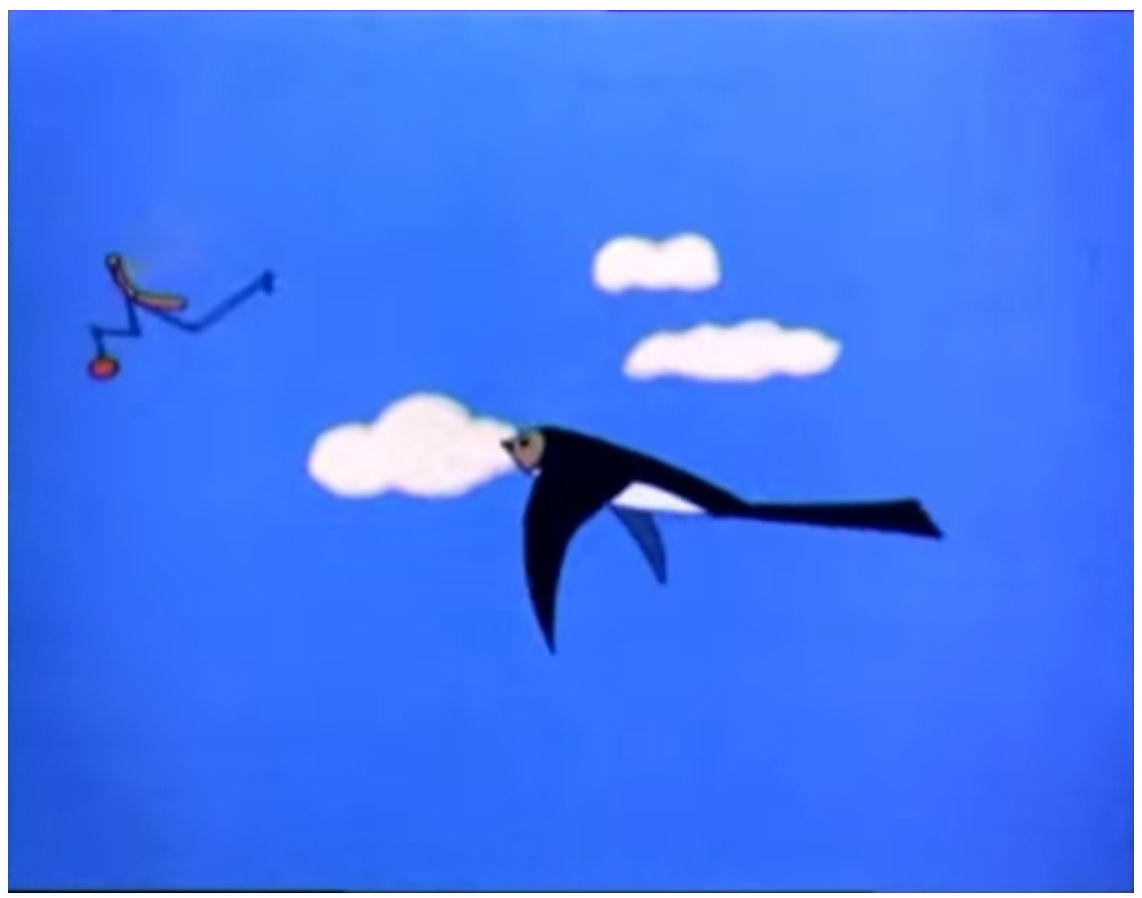

Image 6: Tlendiev's Aqqu plays during the chase scene between the Swallow and mosquito. [Why the Swallow's Tail is Forked, 1967]

After the swallow forces the mosquito to drop the bottle, which crashes into the rocks below, where a group of flowers sprout, the mosquito escapes to the dragon's lair. The swallow pursues it and ultimately ingests the mosquito. As the swallow attempts to escape, the weakened Aüdahar lifts a head and bites the middle feathers from the swallow's tail, the same motif seen in all the folk tale versions. The swallow tumbles to the ground and struggles to flee. In a frantic chase by the dragon and his minions, also represented in the tension of the küu, the swallow narrowly escapes the castle. The dragon king, in his attempt to grab the swallow, crashes through the castle wall and falls to the crags below. The dragon does not die, but explodes and transforms into three snakes that scurry off into the rocks, resonating with Momusholu's account [Image 7]. Nugerbek [2005: 135] makes an astute observation when he writes, “Жамандық жойылған жоқ. Ол бар, həм, ол тек ұтылып қалады. Жамандық қайта жаңғыруы мүмкін. [Evil is not eliminated. It exists; it has just been defeated. Evil can be revived again.]" The 
swallow is incapable of eradicating all evil, but instead allows for its inevitable resurgence.

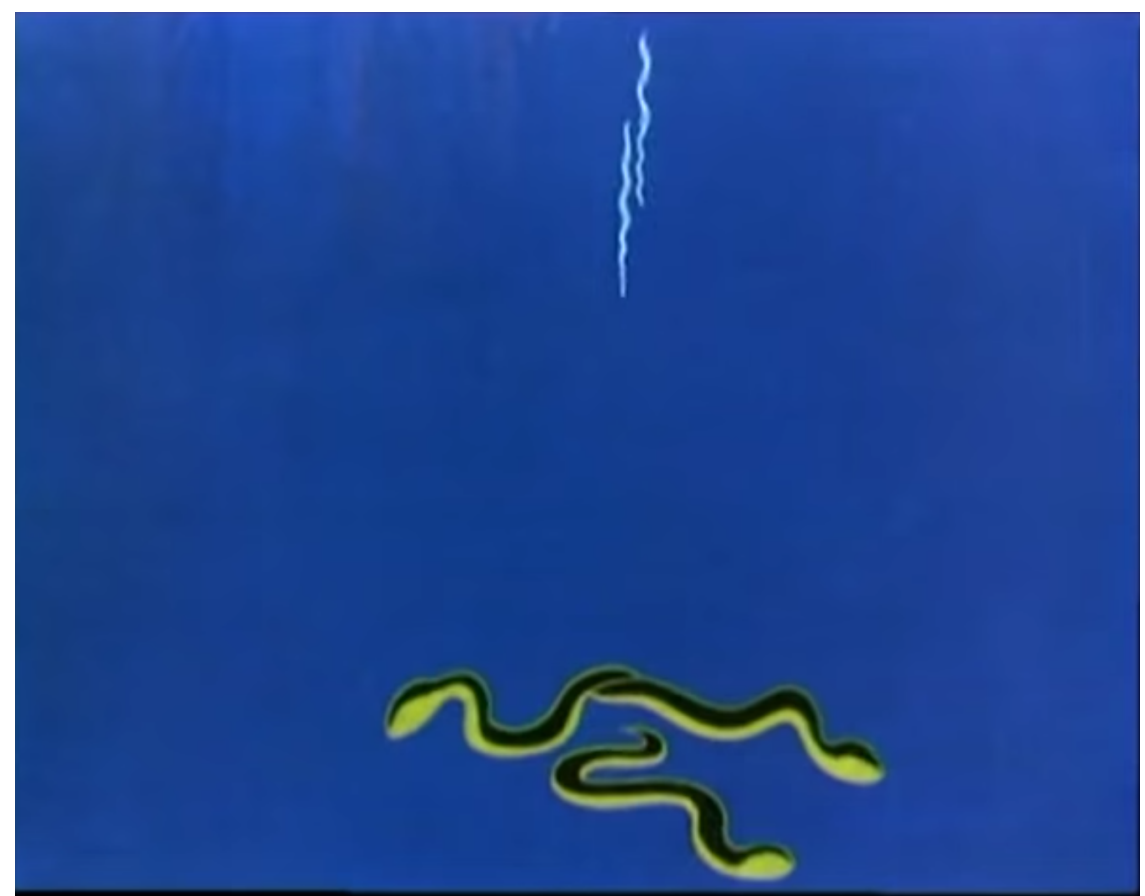

Image 7: After the Aidahar crashed into the ground below, he transforms into three snakes. [Why the Swallow's Tail is Forked, 1967]

This transformation of the dragon king into three snakes is a complex artistic decision on Khaydarov's part. Unlike Momusholu's telling of the story, this change indicates the anticipation of a new threat. The interwoven black and white rope of the toddler's ceremony remains unfrayed; good and evil persist in unison. This ending relates to the film in its capacity as a retelling of a traumatic history. Changing the possible to the inevitable reveals a specifically vulnerable worldview.

The film concludes with the swallow returning to the tree above the mother and the smiling infant. The narrator summarizes the story explaining the swallow's forked tail and the bond between swallow and humans. As the screen fades to black with the end credits rolling, the audience is left with Khaydarov's authentically Kazakh film iteration of a traditional folk tale, or so it seems.

II. Untangling the Roots

In Music as Social Life: The Politics of Participation, Turino [2008] coins the term "semantic snowballing." The term refers to the agglutination of unrelated 
practices into a cohesive entity. His key example of semantic snowballing emanates from his analysis of the recent creation of African nation states. Turino illustrates that Zimbabwean state identity construction was enabled when governments combined various tribal musical performances with speeches from state officials [Turino 2008: 146]. This practice, in effect, snowballs the indexical relationships of the separate tribes and unites them through traditional music underlain by the remarks of government administrators.

Turino's vocabulary allows us to understand Why the Swallow's Tail is Forked as a collection of separate Central Asian cultural elements that have been snowballed into a culminating creation of a unitary notion of Kazakh culture. As I have examined the many elements of this film, it has become apparent that no single element of this film is "uniquely Kazakh." The film, however, is hailed as a true representation of Kazakh identity in contemporary discourse as seen in this quotation by Zhanat Zakiya, Counsellor of the Kazakhstan National Commission for UNESCO, "The animation studio Kazakhmultifilm produced quality classical animation films, representing folklore of the different nations of Kazakhstan and promoting cultural diversity. For example, the film Why the Swallow's Tail Is Forked, made in 1967, was a colossal success" [Bendazzi 2016: 262]. Despite their origin, these elements aspects hold symbolic value for Kazakhs. Thus, we must look to the story itself as a possible representation of Kazakh authenticity as well. By looking at swallow-motif folk tales from different cultural traditions, we can query this conception.

The Italian folklorist Giuseppe Pitrè gathered folk stories about swallows from all over the world in The Swallow Book [2016]. The first story, similar to Momusholu's, is classified as a Circassian legend [Pitrè 2016: 41]. A second version of French origin is considerably shortened, but contains the final scene where a snake bites the middle tail feathers of the swallow [Pitrè 2016: 44]. Other variations of this story include a 1902 version recorded by a Chicago public school principal for students [Holbrook 2009: 19], a 1938 telling in a collection by a daughter of her mother's recount of the tale in Ireland [Martin 1938: 198], and a version in 1907 found in Folk-lore from the Holy Land: Moslem, Christian and Jewish [Hanauer and Pickthall 1907: 283-286]. Just how far back these stories date can never be concretely determined, as there is simply no way to find the beginning of any folk story. However, all of these stories contrast with Khaydarov's film in that the swallow prevents human suffering altogether, as it does in Momusholu's version.

None of the aforementioned versions include a dragon, an evil ruler, a blood sacrifice, a human victim, or a shaman. Additionally, none of the versions illustrate a world of continued subjugation by the inhabitants. These stories acknowledge human blood only in passing, as the tastiest of all. Humans are never the center of the slightly different plots, nor are they involved in any of the other versions beyond appearances as singular characters or as having tasty blood. While Khaydarov's film diverges from these many iterations in different capacities, one thing is certain: this folk tale plot is not exclusively Kazakh either, despite its perception as such. 
Defining "Kazakh"

Scholars such as Sally Cummings [2012] and Bhavna Dave [2007] have studied the development of Kazakh, as well as Central Asian, identity politics and identity formation. As the Kazakh political sociologist Diana Kudaibergenova [2014:160] states regarding national identity formation,

After the collapse of the Soviet Union the newly independent states of Central Asia found themselves having to form their own national "imagined communities," partially to legitimate their existing territorial integrity and the rights of their titular ethnicities. The process of such formation expressed itself in the creation of particular symbols, myths, and rituals that not only would distinguish the nation, but also legitimate their sovereignty. All Central Asian countries were "drawn" and "created" by the Soviet Union in the 1920s.

Prior to Soviet occupation, imperial rulers were little concerned with the steppe nomads. In the mid to late $18^{\text {th }}$ century, Catherine the Great wanted to settle the nomadic peoples in order to make them more "productive," but never followed through with implementation. (30) Nor did any other autocratic ruler, until Josef Stalin [Cameron 2018: 20]. Sarah Cameron informs us that the term "Kazakh" initially referred to a social and ethnic class in the late $15^{\text {th }}$ century [2018: 11]. "Kazakh" referred to the Uzbek-Kazakh khanate located in what is now Uzbekistan, from which many subjects had fled, but scholars speculate that it meant "vagabond" or "adventurer," based on Turkic etymology [Cameron 2018: 24]. The term "Kazakh" became more difficult to define when the Soviets colonized the region. The region that is now Kazakhstan was referred to as the Kirghiz Autonomous Soviet Socialist Republic (ASSR) and the "Kazakh" people as "Kyrgyz," (31) before this territory was changed to the Kazakh ASSR in 1925. While the original definition was not originally an ethnic one, national identity, as imposed by the Soviets, paradoxically became the basis for an ethnic identity. (32)

As Shirin Akiner argues in her book The Formation of Kazakh Identity: From Tribe to Nation-State, Kazakh history is highly disputed [1995: 3]. Although claims about the origin of the ethnic group have been tarnished by ideological and nationalist rhetoric, we can pinpoint the moment when an ostensibly new Kazakh national identity became a prominent socio-cultural and political descriptor of the peoples living in what is now Kazakhstan during the Stalinist period.

Forced Sedentarization and Kazakh Identity Formation

In The Hungry Steppe, Sarah Cameron studies the unfolding of forced collectivization under Stalin in the late 1920s and early 1930s. She demonstrates that the implications of agricultural conversion in the steppe were severely misunderstood by Soviet officials. This led to an avoidable catastrophe resulting 
in the death of over 1.5 million Kazakhs [Cameron 2018: 170]. The devastation to livestock was also destablilizing, with the death of roughly 29,000 livestock out of a total of 40,000 from 1929 to 1931 [Cameron 2018: 109]. While these figures tell a story of mass suffering and loss during forced collectivization, they obscure the larger picture. In the lead up to forced sedentarization and collectivization, the Soviet regime prompted local Kazakhs to purge the loosely determined bourgeois class, "bă," in their dekulakization campaigns [Cameron 2018: 96]. The wholesale destruction of the bă and the massive loss of human life from collectivization decimated the social hierarchy of Kazakhs that had existed for centuries. Clan ties were destroyed, villages were dismantled and relocated, and entire family lineages were lost. The previous notion of Kazakhness, be it the "adventurer," a definition theorized by scholars, or the denotation of the group that had left the Uzbek-Kazakh khanate, had been obliterated.

Nonetheless, Kazakh identity did emerge as a direct result of this decimation. Cameron observes "in the aftermath of the famine, nationality became the most important marker of Kazakh identity" [2018: 172]. All other markers having been removed, "Kazakhness" came to represent a national identity rooted in loss. This new definition placed the nomadic past of the pre-Soviet nomads in a troubled position. Were they "Kazakh?" and was there always a specifically national, as in people belonging to a nation-state, identity for those who lived on the steppe? To answer how this dilemma was resolved, we must examine how the nomadic past has been used to define Kazakh identity in the years following collectivization.

By the time Swallow was released in 1967, three decades after forced collectivization at a time when criticism of Stalinist policies was encouraged, the pastoral nomadic lifestyle was available to be idealized as a fundamental aspect of Kazakh identity. This new view of the past also planted the seed for a nationalist vision after Soviet collapse [Akiner 1995: 2]. The nomadic past was historicized as "Kazakh" to establish continuity between the area in which nomads lived, the Kazakh and proto-Kazakh peoples, and the formation of Kazakhstan as an independent state after the collapse of the Soviet Union [Akiner 1995: 12]. This posited continuity justified the existence of a republic without a primordial or ancient concept of a historical state.

Thus, the film plays a role in this process in multiple ways. It is a product of this Kazakh reimagining of identity with pastoral nomadism at the forefront of the film. With a couple changes in costume and design, or perhaps even none at all, the folk tale could represent Kipchak, Karakalpak, Turkmen, Kyrgyz, Mongolian, or Altaic people, to name several of the many steppe nomads. The combination of the specific elements mentioned in the analysis above, however, is now understood as distinctly Kazakh, because the nomadic past had been firmly rooted as a representation of a particular Kazakh nationalist identity.

As indicated earlier, Turino's concept of semantic snowballing is useful in the analysis of the cultivation and fabrication of Kazakh identity. As we have seen in this brief summary of Kazakh identity, the snowballed "Kazakh" elements in the film were chosen somewhat arbitrarily. The inclusion of particular Kazakh 
motifs, such as blankets, balbals, mosques, carpets, domiciles, etc., helps to create the notion of authentic "Kazakhness," despite none of them being inherently Kazakh. Additionally, none of these elements, I argue, are as integral to the film's reception as the inclusion of the Ädahar, a mythical embodiment of collective loss. When Khaydarov joined these arbitrary cultural elements with a pastoralist vision that incorporated the innovative element of loss, he created a film received as a great Kazakh work of art and a ubiquitous Kazakh cultural artifact in contemporary discourse. (33)

Film and Folklore

No one can ever know how the sparrow folk tale was received by the nomadic people of the steppe, nor its origin. (34) We are better placed to examine how this tale was adapted into a film with such cultural resonance. In $A$ Theory of Adaptation, Linda Hutcheon [2006: 92] describes adaptations as "multilaminated" in their intertextuality. Adaptations always exist in some kind of connection with previous versions. Within adaptations, however, change is inevitable, "and with change come corresponding modifications in the political valence and even the meaning of stories" [Hutcheon 2006: xvi]. Khaydarov's film not only altered the meaning of the folk tale, but his version was well received among audiences, never a guarantee when adapting a classic work. To understand this positive reception, we will look to two classical folklore theorists.

Roman Jakobson and Petr Bogatyrev used Saussure's structural models to understand the retelling of folklore. Their fundamental argument centers on how Saussure's distinction of parole, the individual iteration of language, and langue, the structure of language, act differently in the telling of folk tales. The langue, in this sense, is the consistent qualities of a body or genre of folklore: its structures, plots, and motifs. The parole, in contrast, is the infinite variations of the actual tellings of a folk tale [Jakobson 1966: 4]. At what point a folk tale breaks outside of the langue in its variations is difficult to determine, especially in a case such as Khaydarov's film. Whether or not it exists within the langue of swallow-tail origin stories is irrelevant beyond the fact that it is bound with these other versions in some capacity. Jakobson and Bogatyrev offer insight into the adoption of Khaydarov's version as the supposedly "correct" version of the tale. If the film had not resonated with the audience, if the adjustments to the story's langue had been too extreme, it would have been forgotten. But that was not the case. By stretching the boundaries of the folk tale to include entirely new plot elements, it was embraced by Kazakh audiences as an authentic representation of Kazakh identity in the minds of journalists, animators, and scholars. As Hutcheon [2006: 29] concludes, "palimpsests make for permanent change."

In Rico Isaacs' book Film and Identity in Kazakhstan, he makes a seemingly fair claim about the extremely popular Kazakh film from 1970, Kyz-Zhibek. In regards to director Sultan Khodzhikov's film, he writes [2018: 86], "For the first time on screen Kazakhs were introduced to their nomadic past, erased and forgotten through the Stalinist period, the nomad became real and visceral in Kyz- 
Zhibek, the nomad became sacred." However, Isaacs is mistaken; this film was not the first film to depict this version of the past. He also posits [2018: 89] KyzZhibek as part of a larger pastoralist national vision of Kazakhstan. Swallow predates Kyz-Zhibek by three years, and yet his argument about the national vision holds true. The pastoral nationalist vision emerged at a time distanced enough from the brutal past to become part of the national discourse. Under the new Soviet reality of Khrushchev, denouncing the Stalinist past was not only accepted, but encouraged. It allowed Kazakhs to reclaim, reimagine, and dream up their identity.

Juwen Zhang's analysis of Chinese filmic folklore [2005: 263-280] uses a broad definition of this term that includes films about folklore, e.g., documentaries of local folk culture, as well as folkloric films, e.g., folk tales reimagined on film, animated or otherwise. He finds filmic folklore artificial because it is too far removed from traditional styles of folklore. This approach may explain the indeterminate status of Khaydarov's film in Jakobson and Bogatyrev's usage of langue. Zhang holds [2005: 277] that film adds nontraditional elements to folklore and states the "emergence of filmic folklore shows a historical and social need for reconstructing the cultural identities of China." In the Kazakh context, Swallow supports Zhang's claim. Both Swallow and Khodzhikov's Kyz-Zhibek appeared at a moment in which nomadic pastoralism was recognized and being constructed as part of the Kazakh national identity. Zhang's argument explains not only the dramatic shift of the langue of the folk tale, but also why it emerges at that moment.

A final consideration when thinking of parole and langue is the inclusion of the dragon. Khaydarov's altering of the folk tale establishes the position of Kazakh nomadic pastoralists as always under threat from external rulers, past, present, and future; the swallow does not prevent human suffering altogether, but rather prevents its recursion. This folk tale begins long after the Aldahar has wreaked havoc on its dominion. In dragon-slayer stories where the dragon has killed, eaten, or devastated a human population, the destruction does not last long. As Qiguang Zhao states [1992: 160] in A Study of Dragons: East and West, once a dragon interferes in human affairs, the dragon-slayer arrives. In the film, though, there is no dragon-slayer, only a swallow who saves the nomads from further domination. This dramatic shift to the story's langue could have been rejected outright by audiences, but it was not. Thus, we can interpret this new aspect of loss as integral to the Kazakh pastoralist narrative. Khaydarov's inclusion of the Al̆dahar shows how loss became inseparable to the pastoralist narrative.

Kazakh identity is, in effect, rhizomatic, to borrow Deleuze and Guattari's [1987] useful analytical tool. (35) Identity exists as a structure without a finite beginning or end, without a central unifying factor, but as a culmination of infinite circular pathways. In reading this film, we can see the pastoral nationalist elements in the aftermath of collectivization: tekemet, $\ddot{u} \breve{u}$, cradle board, küu, dombra, headdress, etc. These rhizomatic roots had been cut, but not erased; new systems lead to the same destination, and these new pathways create the façade of aboriginality. The process of tying the manifold aspects portrayed in the film to 
Kazakhness is just as messy and tortuous as the rhizome itself. This model, for all of its infinite complexity, has allowed us to analyze the piece from different perspectives instead of following a single path of analysis.

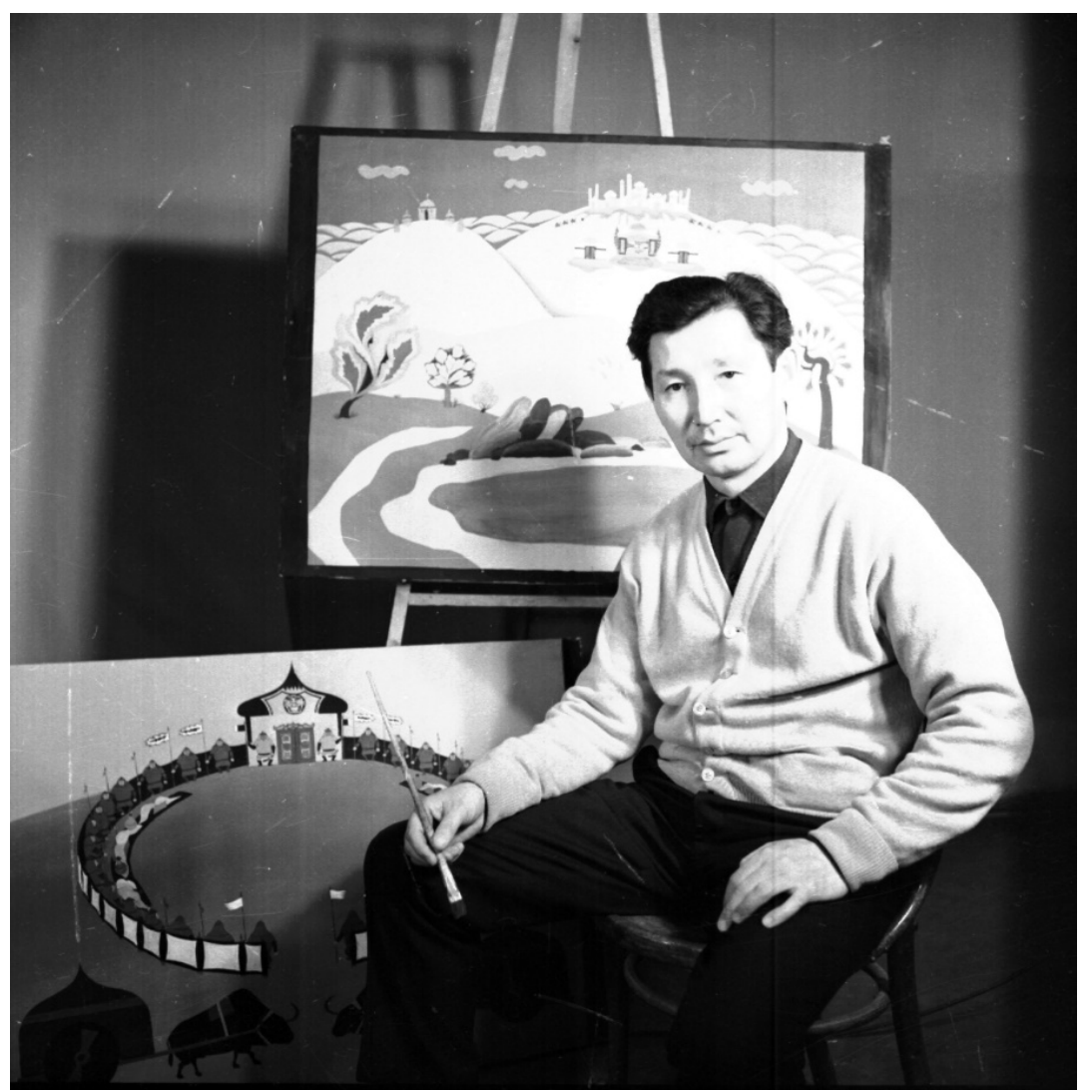

Image 8: A portrait of Amen Khaydarov sitting before frames of his second film "Aqsaq Qülan" [National Film Archive in Almaty, Kazakhstan, 1967]

III. Accidental Resistance

While there is no evidence to support Khaydarov being a resistance filmmaker, Hutcheon [2006: 94] reminds us that "an adaptation can obviously be used to engage in a larger social or cultural critique." Unique to this version of the folk tale is the weakening and dying dragon king. Given that this film was made in 1967, the beginning of Brezhnev's re-freezing of Khrushchev's Thaw, Khaydarov was living in a very different Soviet Union than the one he grew up in. In Mukhamet Shaiakhmetov's memoir following World War II, A Kazakh Teacher's Story: Surviving the Silent Steppe, the author [2012: 158] states how Khrushchev's open criticism of Stalin "sowed the seeds of doubt in the 
infallibility of the people's leader." The desperate effort on behalf of the Ä̈dahar to consume the blood of his subjects could be interpreted as the final straw for Khaydarov. Despite praise from the West for policy advances, the Soviet Union under Khrushchev had been perceived as weakened by many Kazakhs [Shaiakhmetov 2012: 163]. The film could be implying the weakness of the state and the ensuing chaos a vulnerable state can lead to; one that devours its people.

As a firm believer in the socialist project [Khaydarov 2015], it is possible Khaydarov could have been criticizing the weakness of the state as embodied in the new leadership. Regardless of Khaydarov's intentions however, the Alidahar as a concept resonated with Kazakh audiences and continues to resonate to this day.

Fin

In its "animated look" at the film, this essay has attempted to break down the host of "Kazakh" elements in Amen Khaydarov's Why the Swallow's Tail is Forked. The essay began as a thorough investigation of seemingly aboriginal motifs that are actually a part of a popular pastoral nationalist narrative [Akiner 1995: 12]. This vision gained prominence in the late 1960s as pastoral history was open to reflection in the post-Stalinist world. In that remembrance, however, there is an undeniable element of loss, as embodied in Khaydarov's alterations of the folk tale to include the Ă̈dahar. While the pastoral nationalist vision is only one of a variety of nationalist visions in Kazakhstan today, this film helps to position the resurgence of these discourses at its initial creation in 1967 and in recent discourse. This essay hopes to shine light on how seemingly authentic portrayals of national identity are displayed in a popular film, and operates under the assumption that constructed artistic representations can reveal the complexity of nationalist narratives.

My analysis has deconstructed the complex idea of Kazakh identity. Looking at etymological roots, pre-national and national history, collective sedentarization under Soviet occupation, and beyond, I noted that Kazakh nationality is a synthesis of varying components. Understanding the context of these components became foundational in searching for filmic allegory.

This particular analysis has allegorized a film as representative of larger concepts in the realm of Kazakh identity and nation formation. It is an original work of analysis as far as no other source has delved into the subject to this degree, but it certainly has been affected by certain assumptions. The first assumption is that all nations are constructed, as opposed to primordial, and that they can be deconstructed to reveal their internal inconsistencies [Anderson 2006]. Without this assumption, Turino's tool would prove useless, in that snowballs cannot be primordial, and the very deconstruction of this film would be impossible. The act of arguing for the constructionist view of nations takes place within a historical context of the rise of nationalism in 2020. This analysis provides an example of a past popular cultural film and how the assumption of "Kazakhness" is in fact a construction, sometimes so convincing that we forget people have dreamt it into 
existence. This essay should not be faulted for this allegorizing, but rather should be understood in conversation within a particular context at a particular time.

Why the Swallow's Tail is Forked has provided insight to the pastoral nationalist construction. As perhaps the earliest filmic representation of this particular pastoral nationalism, this analysis reveals the amalgamation of that identity. It has also revealed the link between the pastoral national identity and a narrative of loss, as seen in the introduction of the Airdahar into the film. Even in the nostalgic act of reminiscence by contemporary animators, journalists, and academics, the connection of the pastoral identity and perpetual suffering seems obvious. It has therefore become impossible to look back on the nomadic past of those that roamed the Kazakh steppe without prophetically acknowledging the suffering to come. The acts of Khans and bais became trivialized in the looming shadow of the allegorical Aĭdahar.

\section{Acknowledgements}

This essay has been supported by my esteemed colleagues and mentors, without whom this essay would not have come together. Fatima Moldashova, my gracious Kazakh language professor, provided expertise in helping understand the nuance of very difficult Kazakh academic articles and providing support in my academic pursuit. I cannot thank Nelia Lanets Rodriguez enough for her gift of time in accessing Russian, a language beyond my reach. Alma Kunanbayeva shared her life experience, her research expertise, and her personal anecdotes to enrich my interpretations. Gali Murzashev opened his arms wide in greeting me in Almaty, Kazakhstan. He showed me Kazakhfilm Studio and conversed in a type of beautiful spoken Kazakh I had never heard before. Sofia Sultankhan took me into her home and shared valuable experiences and insight. I am fortunate to call her әпкем. My advisors Pavle Levi, Denise Gill, and Gabriella Safran of Stanford University have provided me with constant feedback and supported this project from its inception. I am also thankful to the National Film Archive in Almaty, Kazakhstan for their assistance in this project.

\section{NOTES}

1 The title of the film is sometimes translated from the Russian as Why the swallow has a tail with two little horns, and in the interrogative, Why does the swallow have a forked tail? For the remainder of this paper I will refer to it in the aforementioned to keep with the most common translation into English, or simply as Swallow.

2 Neither I nor Sofia could find an existing copy of the textbook in Olgii, Mongolia.

3 Khaydarov has only been recently referred to as Qaĭdar [Қайдар]. The variations of his name show a quick example of the contemporary political reclamation of Kazakh cultural figures by removing Russification. 
4 This term is also defined as "authorial animation" by Laura Pontieri in Soviet Animation and the Thaw of the 1960s: Not only for children (Bloomington: Indiana University Press, 2012).

5 See Peter Wollen's use of Levi-Strauss in Signs and Meaning in the Cinema (London: Palgrave Macmillan for the British Film Institute, 2013), 105.

6 Widely observed film might also fit within Anderson's conception of "print media" in that it supported those watching it as a part of a larger imagined group.

7 I am grateful to a reviewer for recognizing the need to address Soviet practices of commemoration as a way to build group identity. Further scholarship on the topic includes Maggie Adams' Playing at War: Children's Instsenarovki (skits) in Classrooms and Playgrounds in Soviet Kazakhstan. In Central Eurasian Studies Society Annual Conference. (The Ohio State University, 2011).

8 A personal anecdote from a reviewer stated they remember being told that the animal stories were the oldest and most Kazakh of tales. This contrasts with stories of Gin (genies) that were marked as being Persian or having some other non-Kazakh origin. My essay contends this notion with a close reading of other versions of the folk tale to think differently about Kazakh folk tale origins.

9 See also Robert P. Geraci and Michael Khodarkovsky, Of Religion and Empire: Missions, Conversion, and Tolerance in Tsarist Russia. (Ithaca: Cornell University Press, 2001) 280-288 for the complex relationship Kazakh steppe nomads had with Islam and other religions.

10 The pillars are: 1) Shahada: the pronunciation of faith, 2) Salat: the practicing the five-times daily prayer, 3) Sawm: observing the fasting and obligations of the holy month of Ramadan, 4) Zakat: alms-giving, and 5) Hajj: completing the pilgrimage to Mecca.

11 The significance of the swallow in Kazakh mythology can best be described in the story of the Dzhongar invasion of what is now Kazakhstan. Tole $\mathrm{Bi}$ (also referred to as the "Swallow Bi" because of this very story) was a renowned orator and poet who acted as an advisor to Tauke Khan in the $17^{\text {th }}$ and $18^{\text {th }}$ centuries [Kaskhabasov 2011]. During the Dzhongar invasion of Tauke Khan's territory, all the inhabitants escaped the Dzhongars, except for one lone ii.. Tole Bi awaited the impending arrival of the Dzhongar army. Upon the army's arrival, the Zhongar leader asked, "Why did you stay when you knew we were coming?" Tole Bi told the horseman there was a swallow's nest in his $\ddot{u} \breve{l}$, and that he was unable to move. The horseman nodded in understanding and rode past Tole $\mathrm{Bi}$, respecting the sacred relationship between humans and swallows. This sacred relationship can also be seen in an experience of a fellow Peace Corps Volunteer living in an $u \grave{\imath}$ in rural Mongolia. Towards the end of her volunteer service, a bird nest appeared in the top cross hatch of the $\ddot{u} \bar{l}$. The birds flew in and out of the $\ddot{u} \bar{\imath}$ continuously and upon the babies being hatched, grew exponentially noisier. After days of enduring the commotion she asked her host family if she could move the nest. The Durvod Mongolian host parents were adamant that she not touch the bird nest, as they were sacred. She was offered the option of moving into the house, but the birds had to stay in the $i \check{i}$ until they were ready to leave. 
12 During the pan across the countryside, the Russian language opening credits begin. The lack of Kazakh language credits in the Kazakh language version of the film denotes the secondary importance Kazakh held in Soviet society of the time. Considering the relative ease of layering credits over animation, cost and labor would have been negligible factors in why Kazakh credits were not included.

13 These balbal are believed to have been constructed by a Turkic tribe dating to roughly $500 \mathrm{AD}$ [Basilov, 1989: 59]. The figures are often of warrior men holding a vessel to signify a burial location. Many of these stones still exist in the Central Asian and Mongolian steppe as they are extremely heavy and difficult to steal.

14 "Kazakhness" here refers to an ethnic ideal bearing "authenticity" of traditional ethnic Kazakh culture.

15 See Theodore Craig Levin, Saida Diasovna Daukeeva, and Élmira Kòchümkulova, The Music of Central Asia, (Bloomington, Indianapolis: Indiana University Press, 2016), 278-306 for a comprehensive analysis of the Kazakh kü.

16 Traditionally, this instrument, as well as many other Central Asian instruments, was not taught through written means, but rather apprenticeship.

17 I have heard Tlendiev affectionately referred to as the "god of the küu," and after seeing a recorded performance of him playing two dombyras at the same time, I'm inclined to believe the accolade.

18 This usage can best be understood through the short folk tale, Aqsaq Qülan, which tells the story of the death of a Mongolian Khan's son. The rule of the land was that whoever brought bad news to the Khan would have molten lead poured down his throat. When the Khan's son disappeared, everyone was afraid of telling him what had happened, for obvious reasons. According to the legend, a kiüshi was forced to the court of the Khan and tell him what happened. The kǚshī didn't speak, but rather played a kü telling the story of how the Khan's son died. Upon hearing it, the Khan poured lead down the throat of the dombyra because it was the dombyra that had ultimately spoken the bad news.

19 The novel was initially a series of short stories and was not published as a uniform novel until 1974.

20 This is the biblical King Solomon referred to by his Islamic name.

21 The decision to use the gendered pronoun 'she' for the swallow follows Giuseppe Pitre's usage in The Swallow Book. Kazakh language does not have identifiers for gender in the third person. The swallow in Khaydarov's film is also portrayed as a mother to the two baby swallows. In Russian, "swallow" takes the feminine gender.

22 The ability of King/Prophet Suleiman to speak to animals is the result of a mistranslation of 1 Kings 4:33 and this verse from the Qur'an. "And certainly We gave knowledge to David and Suleiman (a) And they said: Praise be to Allah, Who has made us excel many of His believing servants! 16 And Suleiman was David's heir, and he said: O men, we have been taught the speech of birds, (a) and we have been granted of all things. (b) Surely this is manifest grace" (Qur'an 27:15-16). 
23 Tripartide patterns are common in folk tales: three brothers/sons, daughters, horses, beers, acts for redemption, eyes of the monster, etc. See Propp's Morphology of the Folktale [1968] for further examples.

24 The bylina of Dobrinya and the Dragon [Bailey and Ivanova 2015: 8197 ] is a popular example of a three-headed dragon in Russian folklore.

25 It is important to notice the three minions as unnatural animals. They are unrecognizable and hold traits of various animals in a chimeric fashion. This could be read as underworld creatures aiding the underworld king.

26 The fox in Kazakh mythology holds the position of a trickster figure, and metaphorically sits in direct opposition to wolves. Because the fox hops and jumps as it moves, it makes the fox more difficult to kill thus making it seem crafty and intelligent. The Kazakh language also has a variety of phrases and proverbial expressions that refer to the fox to convey meaning or judgment. If a child wakes from a nightmare the mother will tell the child it was "fox's excrement" [tuilkining boghy], meaning a trick. Another example of this phraseology is the "fox's character" [tuilkining minezī] implying a traitorous or untruthful character of a person. Kazakhs often see themselves as "coming from wolves" which puts the relationship between sedentary and nomadic peoples in perspective when contemporary Uzbeks are sometimes described as "foxlike" or untrustworthy. In the eyes of nomads, they come from separate animal lineages. Additionally, the fox inhabits a liminal space between the Tengrist cosmology as it can move between different realms.

27 This note only exists in Russian. Despite the Kazakh narration, a separate Kazakh language frame did not replace the Russian language note. This may have been a result of funding, oversight, or time constraints, but the frame would have been a relatively easy addition to the film. The decision to not include a Kazakh language frame may indicate the depth of Russification of the Kazakhs. It may have never been acknowledged as potentially exclusive to Kazakh language speakers.

28 For a philosophical take on this relationship between nomads and history refer to Gilles Deleuze and Félix Guattari's A Thousand Plateaus: Capitalism and Schizophrenia (Minneapolis: University of Minnesota Press, 1987), 392.

29 "Musics" is used in the plural to encapsulate all the modes of Central Asian music well beyond the scope of the Western term "music." A kiü and fantastical music must be compared separately, closer to the differences of a sculpture and a painting as opposed to genres of "music."

30 See Michael Khodarkovsky. Russia's Steppe Frontier: The Making of a Colonial Empire, 1500-1800, pgs. 34-39 for Catherine the Great's plans of sending Tatars to make Kazakhs "better Muslims."

31 In superbly racist fashion, the distinction made by the Soviets between Kazakhs and Kyrgyz was based on appearance. Kazakhs were incorrectly identified as Kyrgyz while Kyrgyz were identified as Black Kyrgyz (qara qyrghyz) because of their darker complexion.

32 When living in the Kyrgyz Republic, I often heard the main distinction of Kazakhs and Kyrgyz being that of geography. Kyrgyz lived in the mountains 
and Kazakhs lived on the steppe. In many contemporary Kyrgyz minds, the distinction was as simple as that.

33 I am grateful to my reviewer in pointing out that Kazakh authors of the period realized they could write stories based on appropriated content, which would receive comparatively less attention than Soviet literature. This option gave them some degree of freedom to integrate more critical content.

34 Given the multiple versions of the folk tale predating Khaydarov's, there could be an argument that the film's version attempts to erase the lineage of the folk tale. The film contains many objects and practices deemed as Kazakh which could ignore competing non-Kazakh histories. This analysis of erasure, however, falls outside the scope of this essay.

35 See Deleuze and Guattari, A Thousand Plateaus, 12. The rhizome is used by Deleuze and Guattari to reveal the infinite connections of aspects within an idea. The authors reject "arboreal thought" as having a single root and trunk but instead show the rhizome as a way to temporarily oppose varying ideas. They argue that the dichotomies used in analysis last only as long as necessary and aren't inherent in the structure of thought.

\section{BIBLIOGRAPHY}

Akiner, Shirin. 1995. The Formation of Kazakh Identity: From Tribe to NationState. London: Royal Institute of International Affairs.

Anderson, Benedict R. 2006. Imagined Communities: Reflections on the Origin and Spread of Nationalism. London: Verso.

Bailey, James and Tatiana Ivanova (eds.). 2015. Anthology of Russian Folk Epics (Folklores and folk cultures of Eastern Europe). London: M.E. Sharpe.

Baimyrzaeva, J.A. and M. М. Khorabai. Баймырзаева, Ж.А., and Қорабай, M.M. 2014. "Валалар психологиясы -МультФильмнің бала психикасына тигізер ықпалы” [Children's psychology - how animation influences children's psychology]. Жантану мәселелері: Вопросы психологии 4 (14): 8-13.

Basilov, V. N. 1989. Nomads of Eurasia. Seattle: Natural History Museum of Los Angeles County in association with University of Washington Press.

Bendazzi, Giannalberto. 2016. Animation: A World History: Volume 2, Boca Raton, FL: CRC Press.

Cameron, Sarah I. 2018. The Hungry Steppe: Famine, Violence, and the Making of Soviet Kazakhstan. Ithaca: Cornell University Press.

Cummings, Sally N. 2012. Understanding Central Asia: Politics and Contested Transformations. London: Routledge.

Darmesteter, James. "AVESTA: KHORDA AVESTA (English): Aban Yasht ('Hymn to the Waters')". Cited by http://www.avesta.org/ka/yt5sbe.htm. (consulted 1 May, 2019)

Dave, Bhavna. 2007. Kazakhstan: ethnicity, language and power. New York: Routledge. 
Deleuze, Gilles and Félix Guattari. 1987. A Thousand Plateaus: Capitalism and Schizophrenia. Minneapolis: University of Minnesota Press.

Geraci, Robert P. and Michael Khodarkovsky. 2001. Of Religion and Empire: Missions, Conversion, and Tolerance in Tsarist Russia. Ithaca: Cornell University Press.

Hobsbawm, E. J. and T. O. Ranger. 1992. The Invention of Tradition. Cambridge: Cambridge University Press.

Holbrook, Florence. 2009. The Book of Nature Myths. Chapel Hill, NC: Yesterday's Classics.

Hutcheon, Linda. 2006. A Theory of Adaptation. New York: Routledge.

Hutton, Ronald. 2001. Shamans: Siberian Spirituality and the Western Imagination. London: Hambledon and London.

Ibragimova, Karlyga. Ибрагимова, Қарлыға. 2010. “МультФильмдеріміз батыстың тасасынан қашан шығады?" [When will our animation become known in the west?] Ақ Желкен, No 10.

Isaacs, Rico. 2018. Film and Identity in Kazakhstan: Soviet and Post-Soviet Culture in Central Asia. London: I.B. Tauris \& Co. Ltd.

Jakobson, Roman. 1966. Slavic Epic Studies. The Hague: Mouton. Selected Writings IV.

Jurgenov, T. 2013. “Анимация - ұлы өнер” [Animation - a great art]. Айқын. 22 Sep.

Kengesbaev, T. and G. Mosabaev. Кеңесбаев, Т., және Ғ. Мұсабаев. 1975. Қазіргі қазақ тілі: Лексика, Фонетика [Contemporary Kazakh Language: Lexicon, Phonetics]. Алматы:Мектеп.

Khodarkovsky, Michael. 2004. Russia's Steppe Frontier: The Making of a Colonial Empire, 1500-1800. Bloomington: University of Indiana Press.

Khaydarov, Amen. Қайдаров, Әмен. 1967. Қарльваштың құйрывы неге айыр [Why the Swallow's Tail is Forked]. Kazakhfilm Studio.

Khaydarov, Amen. Қайдаров, Әмен. 2015. “Основоположник казахской анимации, художник, кинорежиссер. Некролог” [Founder of Kazakh animation, artist, film director. Obituary]. Казахстанская правда. Февраля 6.

Kotkin, Stephen. 1995. Magnetic Mountain: Stalinism as a Civilization. Berkeley: University of California Press.

Kozlov, Denis and Eleonory Gilburd. 2013. The Thaw: Soviet Society and Culture During the 1950s and 1960s. Toronto: University of Toronto Press. 402435.

Kudaibergenova, Diana. 2014. "National identity formation in post-Soviet Central Asia: The Soviet legacy, primordialism, and patterns of ideological development," in Social and Cultural Change in Central Asia: The Soviet Legacy. Sevket Akyildiz and Richard Carlson, (eds.). United Kingdom: Routledge. 160-173.

Kunanbayeva, Alma. 2019a. Personal Interview. Stanford, 23 February.

Kunanbayeva, Alma. 2019b. Personal Interview. Stanford, 9 March. 
Levin, Theodore Craig. 1996. The Hundred Thousand Fools of God: Musical Travels in Central Asia (and Queens, New York). Bloomington: Indiana University Press.

Levin, Theodore. 2012. "Why Music Matters." 24th Faculty Presidential Lecture, Dartmouth University. Hanover, New Hampshire. February 28. Lecture.

Levin, Theodore Craig, and Valentina Süzükei. 2006. Where Rivers and Mountains Sing: Sound, Music, and Nomadism in Tuva and Beyond. Bloomington: Indiana University Press.

Levin, Theodore Craig, Saida Diasovna Daukeeva, and Ėlmira Kóchümkulova. 2016. The Music of Central Asia. Bloomington, Indiana : Indiana University Press ; [S.1.] Aga Khan Trust for Culture, Music Initiative.

Lord, Albert Bates. 1960. The Singer of Tales. Cambridge: Harvard University Press.

Lukonin, Vladimir and Anatoli Ivanov. 2013. Central Asian Art. New York: Parkstone Press International.

Martin, Annie.1938. Interview. "Why the Swallow has a Forked Tail Story as told by Mary Martin". The Schools' Collection 1013. National Folklore Collection, University College Dublin. 198-199.

Momusholu, Baurjan. Момышұлы, Бауыржан. 2003. Ұмқан Ұя [Our Family] Алматы: Атамұра.

Nugerbek, B.R., G.K. Nauryzbekova and N. R. Mokysheva. Нөгербек, Б.P., Наурызбекова, Г.Қ., Мұқышева Н.Р. 2005. Қазақ Киносының Тарихы: Окулық [History of Kazakh Film: Textbook]. Алматы: ИздатМаркет.

Nugerbekov, Bauyrjan. Нугербеков, Бауыржан. 1980. "МультФилм: Фольклор, образ, характер" [Animation: Folklore and Character]. Простор 8. 134-138

Nursan, Alimbay (ed.). Әлімбай, Нұрсан (ред.). 2011. “АЙДАһАР,” [Dragon], in Қазақтың этнографиялық категориялар, ұвымдар мен атауларының дастүрлі жүйесі. Энииклопедия [The Traditional System of Ethnographical Categories Conceptions and Designations of Kazakhs: Encyclopedia]. Алматы: DPS. Том 1.87

Nysanbaev, А. Нысанбаев, Ә. 1998. Қазаққстан: Ұлттық эниклопедия [Kazakhstan: National Encyclopedia]. Алматы: Қазақ энциклопедиясы. VIII том.

Orozbaeva, Raushan. 2014. "'Aqqu' (White Swan), Folk küi performed by Raushan Orozbaeva. Filmed by Saodat Ismailova." Cited by https://musicofcentralasia.azurewebsites.net/Tracks/Chapter/16. (consulted 10 Dec, 2018).

Pitrè, Giuseppe and Ada Walker Camehl. 2016. The Swallow Book: The Story of The Swallow Told in Legends, Fables, Folk Songs, Proverbs, Omens and Riddles of Many Lands. Sacramento, CA: Creative Media Partners LLC. Scholars Select.

Pontieri, Laura. 2012. Soviet Animation and the Thaw of the 1960s: Not Only for Children. Bloomington, Indiana.: Indiana University Press. 
Privratsky, Bruce G. 2015. Muslim Turkistan : Kazak Religion and Collective Memory. London: Routledge.

Propp, V. IA, Svatava Pírková-Jakobsonová, Louis A. Wagner, and Alan Dundes. 1968. Morphology of The Folktale. Austin: University of Texas Press.

Róheim, Géza and Alan Dundes. 1992. Fire in the Dragon and Other Psychoanalytic Essays on Folklore. Princeton, N.J.: Princeton University Press.

Rozwadowski, Andrzej and Maria M. Kośko. 2002. Spirits and Stones: Shamanism and Rock Art in Central Asia and Siberia. Poznań: Instytut Wschodni UAM.

Seitzhanov, Z., V. Ponomareva, and Q. Baigabulov. Сейітжанов, 3., Пономарева, В., және Байғабылова, Қ. 2017. “Халық ауыз әдебиеті: Жануарлар түралы ертегілер" [Kazakh Oral Literature: Animal Folk Tales]. Алматы: Аруна LTD. ЖШС.

Shaiakhmetov, Mukhamet. 2012. A Kazakh Teacher's Story: Surviving the Silent Steppe. London: Stacey International.

Sultankhan, Sofia. 2019. Personal Interview. Stanford, 12 June.

Torsynbaiuly, Bagashar. Тұрсынбайұлы, Бағашар. 2012. “'Қарлығаш’ Қазақ баласын қалай қуантты?” [How Do Kazakh Children Enjoy “Swallow”?] Жас Өркен. 10-11.

Tousi, Hakim Abol Qasem Ferdowsi. "Shahnameh". Адабиёти ниёгон / Perso

Tajik Literature / Персо Таджикская Литература. Cited by https://www.sattor.com/index.html. (consulted May 2, 2019).

Turino, Thomas. 2008. Music as Social Life: The Politics of Participation. Chicago: University of Chicago Press.

Wollen, Peter. 2013. Signs and Meaning in the Cinema. London: Palgrave Macmillan for the British Film Institute.

Zarcone, Thierry, and Angela Hobart. 2013. Shamanism and Islam: Sufism, Healing Rituals and Spirits in the Muslim World. London: I.B. Tauris.

Zawlacki, Jake. 2019. "An Interview with an Animator: Gali Murzashev." Stanford Arts Review. (hyperlink no longer available) (consulted 4 June, 2019).

Zawlacki, Jake and Matthew Derrick. 2020. “An Examination of Contemporary Use of the Traditional Nomadic Infant Cradle Board (beshik) Among the Kyrgyz of Bishkek, Kyrgyzstan," International Journal of Russian Studies 9 (1): 64-79.

Zhang, Juwen. 2005. "Filmic Folklore and Chinese Cultural Identity." Western Folklore 64 (3/4): 263-80.

Zhao, Qiguang. 1992. A Study of Dragons, East and West. New York: P. Lang. 